\title{
Todo empieza con «E»: Exclusión, etnicidad y formación de élites en el mundo actual de las discotecas inglesas
}

\section{Everything Starts with an 'E': Exclusion, ethnicity and elite formation in contemporary English clubland}

\author{
I FIONA MeASHAM*; PhIL HADFIELD**
}

\author{
* Profesora titular de Criminología \\ Universidad de Lancaster \\ ** Investigador titular de Delincuencia y Gobernación \\ Universidad de Leeds \\ Enviar correspondencia a: \\ Fiona Measham. Lancaster University \\ F.Measham@lancaster.ac.uk
}

\section{RESUMEN}

Los primeros estudios sobre las discotecas se centraban en la identificación de la cultura de discoteca con el espíritu PAUR de "paz, amor, unidad y respeton y en una definición polarizada de los contextos nocturnos: por un lado discotecas comerciales e interesadas en fomentar el consumo de alcohol, que ofrecian música pop "del montón», y por otro discotecas underground "auténticas»/«alternativas» vinculadas al consumo generalizado de drogas ilegales. Este artículo se suma al creciente número de trabajos de investigación que cuestionan estas simplistas caracterizaciones de la cultura de las discotecas y de los lugares de diversión vinculados al ocio nocturno y subrayan los elementos de fragmentación y segregación junto a la importancia permanente de la estructura social y la exclusión social y espacial resultante. Los autores estudian cómo los procesos informales -aperturas de discotecas, promociones en Internet y códigos de vestuario- dan lugar a la producción y reproducción de dos élites inglesas opuestas en torno al mundo de las discotecas: las "élites culturales» derivadas de la exclusión social, cultural y espacial de la música dance electrónica de origen negro y su minoria étnica, con seguidores de clase obrera y rentas bajas en las discotecas dance del centro de la ciudad de Manchester; y las "élites consumidoras» derivadas de la exclusión cultural y económica de los clientes obreros y de rentas bajas de las discotecas del West End londinense. Las complejas y entrecruzadas prácticas de distinción cultural y discriminación estructural que producen dichas élites se relacionan estrechamente con la reglamentación formal e informal, la marginación y la criminalización de determinadas manifestaciones culturales. Este artículo aboga por la elaboración de consideraciones conceptuales más matizadas de las divisiones y desigualdades sociales en la vida nocturna y en los estudios sobre las oportunidades de ocio de los jóvenes desde una perspectiva más general.

Palabras clave: Economía del ocio nocturno, etnicidad, clase social, seguridad.

\section{ABSTRACT}

Early Club Studies emphasised the inclusiveness of club cultures and the PLUR ethos of 'peace, love, unity and respect' alongside a polarised characterisation of nightlife contexts, as either commercial, alcohol-oriented nightclubs offering 'mainstream' pop music, or 'authentic'/'alternative' underground dance clubs associated with widespread illicit drug use. This paper adds to the growing body of research problematising these simplistic characterisations of club cultures and leisure venues across the night-time economy, emphasising elements of fragmentation and segregation alongside the continued importance of social structure and resultant social and spatial exclusion. The authors explore how informal processes - such as club launches, internet promotions and dress codes - together result in the production and reproduction of two contrasting forms of English clubland elites: 'cultural elites' produced through the social, cultural and spatial exclusion of electronic dance music of black origin and its minority ethnic, working class and lower income followers from Manchester city centre dance clubs; and 'consumer elites' produced through the economic and cultural exclusion of working class and lower income club-goers from nightclubs in London's West End. The complex and interweaving practices of cultural distinction and structural discrimination which produce such elites are often closely intertwined with the formal and informal regulation, marginalisation and criminalisation of specific cultural forms. The paper therefore argues for the construction of more nuanced conceptual understandings of the social divisions and inequalities within nightlife and in studies of young people's leisure opportunities more generally.

Key words: Night time economy, ethnicity, social class, security, 


\section{INTRODUCCIÓN}

D esde los primeros estudios sobre los ambientes discotequeros de acid house, rave y música dance, se observaron dos características esenciales en todo el mundo. En primer lugar, se resaltó la inclusión de la cultura de discoteca en el espíritu de "paz, amor, unidad y respeto" (a partir de ahora PAUR) de los inicios del acid house y el rave, y luego en la ética comunitaria y la espiritualidad que se identifican con los ambientes contemporáneos de música electrónica dance $^{1-4}$. En época más reciente, los estudios sobre las discotecas han dejado de lado la ética comunitaria y la inclusión para analizar las divisiones y diferencias sociales ${ }^{5,6}$. En segundo lugar, se distinguió una dicotomía que afecta a la asociación de las discotecas comercialmente rentables con la música popular "corriente", los estilos "pijos" y el consumo de alcohol (casi siempre en exceso); en comparación con la asociación de discotecas dance "underground" menos rentables comercialmente, y de fiestas rave sin permiso o ilegales con música "alternativa", una estética "auténtica» o "guay" y el consumo de drogas de discoteca,8. Sin embargo, ambos temas -la idea de un espíritu PAUR de inclusión dominante en la cultura de discoteca, y la dicotomía entre comercial/ "popular" por un lado y "auténtico»/underground por otro- han sido cada vez más cuestionados a partir de la década de 1990, tanto desde dentro como desde fuera del campo de los estudios sobre el mundo de las discotecas $5^{9,10}$. Por otro lado, en Gran Bretaña la regeneración de zonas urbanas a través de la expansión de la economía del ocio nocturno (en adelante EON) ha generado el desarrollo de un cuerpo paralelo de investigaciones sociales que analizan el contenido y el contexto de la vida nocturna "popular»"1,12. Sin embargo, sigue dominando la noción de un espiritu PAUR incluyente dentro de la cultura de discoteca y de una dicotomía entre vida nocturna comercial/ «popular» frente a la "auténtica"/underground ${ }^{13}$, con tipologías de nightclubs y de discotecas que hasta la fecha han minimizado el nivel de comercialización que existe en las culturas de discoteca contemporáneas y el alcance de la diferenciación y fragmentación dentro de la corriente denominada "popular»"

Este artículo basa su análisis en una considerable cantidad de investigaciones empíricas realizadas por los autores in situ, en una serie de locales de ocio autorizados de la EON, que abarcan estos aspectos. En primer lugar, la investigación de Measham sobre las dos últimas décadas ha estudiado ampliamente las cambiantes culturas de consumo de sustancias en los pubs, bares, discotecas y nightclubs ingleses; su estudio sobre las fiestas rave y el ambiente dance a partir de 1990 condujo a la consiguiente inclusión de la música jungle/drum and bass desde el principio ${ }^{15,16}$. En segundo lugar, los trabajos de investigación de Hadfield sobre las culturas nocturnas populares se basaron inicialmente en diez años de experiencia como disc jockey dance y comercial en una serie de locales y en su posterior investigación sobre los permisos, la seguridad y la gobernabilidad dentro de la EON ${ }^{17,18}$. En tercer lugar, este artículo se fundamenta asimismo en observaciones sobre casi 600 locales autorizados de toda Inglaterra, recogidas por Measham, Hadfield y un equipo de 26 observadores como parte de un reciente estudio del Ministerio

\section{INTRODUCTION}

- rom some of the earliest studies of acid house, rave - and dance club scenes, there have been two key recurring characteristics identified across the world. Firstly, there has been an emphasis on the inclusiveness of club cultures from the 'peace, love, unity and respect' (hereafter PLUR) ethos of early acid house and rave through to the communality and spirituality identified in contemporary electronic dance music scenes. ${ }^{1-4}$ More recently, club studies have shifted their emphasis from communality and inclusion, to explorations of social divisions and difference. ${ }^{5,6}$ Secondly, a dichotomous distinction has been made involving the association of commercially profitable nightclubs with 'mainstream' popular music, 'high street' styles and (often excessive) alcohol consumption; contrasted with the association of less commercially profitable 'underground' dance clubs, unlicensed or illegal raves with 'alternative' music, an 'authentic' or 'cool' aesthetic and the consumption of club drugs. ${ }^{78}$ However, both these themes - the notion of a preeminent PLUR ethos of inclusiveness in club cultures and the notion of a commercial/'mainstream' versus 'authentic'/ underground dichotomy - have been increasingly challenged since the 1990s both within and outside of the field of Club Studies. ${ }^{9,10}$ Added to this, in the UK the regeneration of urban areas through the expansion of the night-time economy (hereafter NTE) has also led to the development of a parallel body of social research dissecting the content and context of 'mainstream' nightlife. ${ }^{11,12}$ Yet, notions of an inclusive PLUR ethos within club cultures and of a commercial/'mainstream' versus 'authentic'/ underground nightlife dichotomy remain prominent, ${ }^{13}$ with typologies of nightclubs and dance clubs to date having tended to minimise both the degree of commercialisation that exists within contemporary club cultures and the extent of differentiation and fragmentation within the so-called 'mainstream'. ${ }^{4}$

This paper draws analysis from a sustained body of empirical research conducted by the authors in situ in a range of licensed leisure venues across the NTE which cut across these discourses. Firstly, Measham's research over the last two decades has broadly explored changing cultures of intoxication within English pubs, bars, dance clubs and nightclubs, with her rave and dance club research from the early-1990s onwards drawing on her ongoing participation in the jungle/drum and bass scene since its inception. ${ }^{15,16}$ Secondly, Hadfield's body of research on populist nightlife cultures was initially informed by his 10-year experience as a dance and commercial disc jockey in a range of nightlife settings and his subsequent academic research on licensing, security and governance within the NTE. ${ }^{17,18}$ Thirdly, this article also draws upon observations in nearly 600 licensed premises across England, conducted by Measham, Hadfield and a team of 26 observers as part of a recent Home 
del Interior sobre los criterios de responsabilidad social de la industria del alcohol ${ }^{19}$.

Las prácticas formales e informales de empresarios, gerentes, personal de seguridad y clientes contribuyen a la regulación del espacio de ocio dentro de la EON. Esto se produce a través de la creación, lanzamiento y continuación de eventos concretos, cuyo carácter suele ser fluido, desafía la reducción a categorias simplistas y refuerza las tendencias emergentes de diversificación, fragmentación y reorganización espacial de los lugares de ocio ${ }^{10,11,20}$. Estos procesos determinan que, mientras que en ciertos contextos, como las zonas más concurridas de las ciudades o los barrios de diversión nocturna de los centros turísticos costeros, existe una gran similitud de funcionamiento entre locales (y de movimiento de clientes entre ellos), la EON no es algo social y culturalmente homogéneo ni polarizado, y una investigación basada en observaciones refinadas sin duda revelará sutiles diferencias no sólo entre ambientes de ocio, sino también dentro de los mismos ${ }^{\mathrm{a}}$. Y así, las variantes de la simplista dicotomía entre comercial/«popular» por un lado y "auténticon/underground por otro, no reflejan de forma adecuada esas experiencias nocturnas más fluidas y llenas de matices. En resumen, y al menos en el contexto inglés, no soportan un análisis empírico sistemático. Resultan útiles para que los investigadores e interesados diferencien entre «bares y discotecas en los que domina el alcohol" y "discotecas underground en las que predominan las drogas», pero cuando se estudia el uso que se da a esos lugares y lo que en ellos se consume, las cosas no están tan claras. Por ejemplo, un reciente estudio sobre el consumo de drogas en la EON de una ciudad inglesa puso de manifiesto que aparte de dos de cada tres clientes de discotecas, uno de cada cinco clientes de bares habian tomado o previsto tomar drogas ilegales en el ambiente nocturno ${ }^{13}$. En la vida nocturna existen indudables divisiones sociales y culturales, pero a nuestro modo de ver son múltiples, fragmentadas y están estrechamente vinculadas a las normas formales e informales, a la marginación y a la criminalización de formas culturales concretas, estudiadas aquí en relación a la formación de élites del mundo recreativo nocturno.

Nuestro trabajo estudia esta diversidad en la EON, centrándose en los procesos que dan lugar a la producción y reproducción de dos formas opuestas de élites de discotecas; lo que aqui denominamos una "élite cultural», nacida de la exclusión social, cultural y espacial de la música dance electrónica (en adelante MDE) de origen negro y de sus seguidores, una minoría étnica de clase obrera y con rentas bajas que frecuenta las discotecas del centro de la ciudad de Manchester; y una "élite consumista" producida por la exclusión económica y cultural de los clientes de clase obrera y rentas bajas de las discotecas del West End londinense. Estos dos ejemplos de exclusión y de formación de élites ejemplifican la creciente segregación y fragmentación dentro de la MDE y en la EON inglesa, y cuestionan la homogeneidad de las caracterizaciones comercial/ "popular» por un lado y "auténtica»/underground por otro tras identificar una serie de prác-

a Véase un análisis de "ambientes» en Measham and Moore. ${ }^{13}$ Véase también Moore, D.
Beyond 'subculture' in the ethnography of illicit drug use, Contemporary Drug Problems Beyond 'subculture' in the eth
2004; 31, Summer, p.181-212.
Office review of the alcohol industry social responsibility standards. ${ }^{19}$

The formal and informal practices of promoters, managers, security staff and customers help shape the regulation of leisure space within the NTE. This occurs through the inception, launch and continuation of specific club events, the nature of which are often fluid, serving to defy simplistic categorisation and reinforce emergent trends in the diversification, fragmentation and spatial re-organisation of leisure spaces. ${ }^{10,11,20}$ These processes ensure that whilst in some contexts, such as the night-time 'high street' or the 'night strips' of seaside resorts, there may be a great deal of functional similarity between venues (and indeed movement of customers between them), socially and culturally the NTE is neither homogenous nor polarised, with fine grained observational research likely to reveal subtle differences not only between, but also within local leisure scenes. ${ }^{\text {a }}$ Thus, variants of the simple dichotomous typology of commercial/'mainstream' versus 'authentic'/underground are unable to adequately reflect these more fluid and nuanced lived experiences of nightlife. In short, in the English context at least, they fail to withstand systematic empirical testing. Whilst it may have proved convenient for researchers and stakeholders to differentiate 'alcohol-oriented bars and nightclubs' on the one hand, from 'underground, drugoriented dance clubs' on the other, when one explores the ways in which such spaces are actually used and consumed things become much less clear-cut. For example, a recent survey of drug use across the NTE in an English city found that alongside nearly two-in-three club customers, one-infive bar customers either had taken, or anticipated taking, illicit drugs on the fieldwork night. ${ }^{13}$ Whilst social and cultural divisions undoubtedly do occur across nightlife, we contend that these are multiple, fragmented, and often closely intertwined with the formal and informal regulation, marginalisation and criminalisation of specific cultural forms, here considered in relation to the formation of clubland elites.

Our paper explores this diversity across the NTE, focussing on the processes which result in the production and reproduction of two contrasting forms of clubland elite; what we here term a 'cultural elite' produced through the social, cultural and spatial exclusion of electronic dance music (hereafter EDM) of black origin and its minority ethnic, working class and lower income followers from Manchester city centre dance clubs; and a 'consumer elite' produced through the economic and cultural exclusion of working class and lower income club-goers from nightclubs in London's West End. Together, these two examples of exclusion and elite formation illustrate the growing segregation and fragmentation both within EDM and across the English NTE, challenging the homogeneity of commercial/'mainstream' and 'authentic'/underground characterisations through the 
ticas interrelacionadas de distinción cultural y discriminación estructural en los establecimientos con un amplio espectro de políticas publicitarias, musicales y de admisión de clientes. En este artículo estudiamos tres procesos que, a nuestro modo de ver, contribuyen a producir y a reproducir las élites culturales y consumidoras dentro de la EON: la organización inicial de eventos en discotecas, las estrategias de promoción en Internet, y las políticas de admisión o los códigos de vestuario asociados al aspecto de los clientes potenciales. Antes de abordar esos procesos, nos fijaremos en formulaciones recientes de las teorías sobre las élites, en el desarrollo de las economías de ocio nocturno de Manchester y Londres y en estudios sobre la música de origen negro.

\section{Las élites en el mundo de las discotecas}

En los últimos años existe un vacío en la investigación social sobre las élites. Savage y Williams se han preguntado por qué hay una "invisibilidad tan escandalosa de las élites» dentro de las ciencias sociales cuando los uricos viven cada vez recluidos en sus privilegiados mundosı ${ }^{21}$. Scott, uno de los principales sociólogos estudiosos de las élites, cuyo trabajo parte de la teoria weberiana de las élites, ha destacado la importancia del concepto de élite en cuanto permite una consideración del poder estructural junto con un análisis de "la parte que juega un papel colectivo en el ejercicio de ese poder ${ }^{22}$. En tiempos más recientes, Bourdieu ha sido uno de los pocos teóricos sociales que han estudiado las élites en el mundo contemporáneo con su obra fundamental sobre los profesores y funcionarios, en la que desarrolla el concepto de "capital" detentado por grupos dominantes ${ }^{23}$. La obra de Bourdieu ha perfilado nuestra comprensión conceptual de la formación de las élites al afirmar que el capital debe entenderse no sólo en términos de valores económicos, sino también de habilidades educativas y sociales, evidentes en las normas y gustos característicos de las élites, notables por su prestigio.

Por el contrario, Scott critica el uso indiscriminado del concepto de élite y en particular su aplicación a grupos sin relación formal con el poder. Aceptamos su prevención contra la constante ampliación del término fuera de las estructuras formales de poder, pero preferimos utilizar el concepto más extenso de Savage y Williams sobre las élites y su idea más fluida de la relación entre estructuras de poder formales e informales y el funcionamiento de una agencia colectiva, vinculada a los procesos de distinción identificados por Bourdieu, en nuestra identificación de las élites culturales y comerciales dentro del mundo del ocio nocturno.

En relación al ocio nocturno en concreto, Perrone ha aplicado el concepto de Bourdieu de culturas del gusto para analizar el efecto de "túnel y puente» (ajeno a Manhattan) de las actitudes, conductas y consecuencias de los jóvenes con respecto a las drogas y a los locales de ocio en su estudio etnográfico sobre los "chicos de discoteca" (club kids) de Nueva York ${ }^{24}$. Perrone observó que, en el caso de los relativamente acomodados y bien educados "chicos de discoteca", identification of complex interweaving practices of cultural distinction and structural discrimination in venues with a wide range of different promotional, music and door policies. Three processes are explored here which we suggest help produce and reproduce these cultural and consumer elites within the NTE: the initial establishment of club events; internet promotional strategies; and admissions policies or dress codes relating to the appearance of potential customers. Before considering these processes, we first note some recent developments in the theorisation of elites, the development of the Manchester and London club economies and studies on music of black origin.

\section{Elites in Clubland}

There has been a hiatus in social research on elites in recent years. Indeed, Savage and Williams have posed the question why do we have such a "glaring invisibility of elites" within the social sciences, given that "the rich draw away and inhabit their ever more privileged worlds" ?21 Scott, one of the leading sociologists of elites whose work draws on Weberian elite theory, has emphasised the importance of the concept of elites in allowing a consideration of structural power alongside an exploration of "the part played by collective agency in the exercise of this power".22 More recently, Bourdieu has been one of very few social theorists to have considered elites in contemporary times, with his seminal work based on studies of academics and civil servants developing the concept of 'capital' held by dominant groups. ${ }^{23}$ Bourdieu's work has further advanced our conceptual understanding of the formation of elites, arguing that capital should be understood not only in terms of economic assets, but also educational and social skills and cultural capital evident in the distinctive norms and tastes of elites which are notable for their prestige value.

By contrast, Scott warns of the indiscriminate use of the concept of elites, and in particular its application to groups without a formal relationship to power. Whilst recognising this cautionary note on the continued broadening of the term beyond formal power structures, we would like to utilise Savage and Williams' wider conceptualisation of elites and their more fluid understanding of the relationship between both formal and informal power structures and the operation of collective agency, allied to the processes of distinction identified by Bourdieu, in our identification of cultural and commercial elites in clubland.

In relation to clubland in particular, Perrone has applied Bourdieu's notion of taste cultures to explore the 'tunnel and bridge' (non Manhattan-based) young people's drugrelated and clubbing-related attitudes, behaviours and consequences, in her ethnographic study of New York 'club kids'. ${ }^{24}$ For the relatively affluent and well educated 'club kids' she observed, what was notable was how their economic, social and human capital assisted them in avoiding 
su capital económico, social y humano les permitía evitar el indeseado peso de la justicia criminal y de las intervenciones médicas, frente a sus colegas menos acomodados. Este hecho permitía a ese grupo concreto de clientes de discoteca mantener estilos de vida productivos y llegar a la edad adulta sin sufrir riesgos significativos de daño a largo plazo a consecuencia de sus incursiones en las discotecas y las drogas, lo cual les facilitaba en consecuencia mantener y reproducir su estatus de élite.

\section{Etnicidad y exclusión en el mundo de las discotecas de Manchester}

Los estudios sobre la regeneración económica de Gran Bretaña en la década de 1990 observaron que los centros de las ciudades se habian convertido en lugares de notable consumo de sustancias, con una vida nocturna a la vanguardia del desarrollo de las nuevas "ciudades de fiestas de 24 horas" y con los dueños de las discotecas en el papel de "empresarios subculturales" dentro de la floreciente industria del ocio $0^{6,11,25,26}$. Mientras la ciudad fue y sigue siendo una sólida metáfora de la diversidad y el peligro ${ }^{27,28}$, y se ha analizado en profundidad la asociación entre clase obrera y culturas étnicas minoritarias con la "peligrosidad", tanto históricamente ${ }^{29-32}$ como en la cultura contemporánea ${ }^{10}$, la antedicha regeneración económica ha perpetuado y reforzado procesos de exclusión preexistentes que dieron lugar a ciertas manifestaciones musicales y a que algunos clientes no fuesen bien recibidos en las "fiestas de 24 horas".

En cuanto a los procesos formales de regulación, el estudio de Böse sobre la vida nocturna de Manchester demostró que las políticas selectivas y la discriminación racial afectaban desproporcionadamente a los grupos marginados. Böse describe la exclusión de las minorías étnicas de las discotecas del centro de Manchester en los años 70 y 80 y su reclusión en los guetos deteriorados tanto a efectos residenciales como de ocio, con instalaciones carentes de la calidad, el glamour o el atractivo de los establecimientos céntricos ${ }^{6,28}$. Talbot y Böse, en sus estudios sobre Londres y Manchester, describen cómo en la década de 1990 surgieron nuevas formas de gobernabilidad discriminatoria, en las que los "espacios culturales negros" estaban "sujetos a procesos de exclusión" de "los nuevos centros de recreo de la economía del ocio nocturno" ${ }^{33}$. Böse observa que Manchester, una ciudad en la que aproximadamente el 15\% de la población no es blanca, es famosa por las iniciativas culturales y creativas producidas y consumidas en su mayor parte por la población blanca. Por tanto, dichas iniciativas no reflejan toda la gama de experiencias urbanas contemporáneas.

Kirby estudió a partir de finales de los años 90 la exclusión del ambiente MDE de dos géneros musicales derivados de la "música de garaje británica" y denominados grime y niche (bassline o ritmos bajos) ${ }^{34}$. Ante la radical eliminación de algunas formas musicales de origen negro ${ }^{b}$, como el grime

En este artículo se utiliza el término "negro» en vez de "urbano" para subrayar
que géneros de MDE como el jungle, el drum and bass, el dubstep, el grime y el
niche tienen sus raices históricas en las manifestaciones culturales de la diáspora
africano/caribeña. Kirby observa que "hay que tener en cuenta que la música negra unwelcome criminal justice and medical interventions unlike their less affluent peers. This allowed this particular group of club-goers to maintain productive lifestyles and emerge into adulthood without a significant risk of long-term harm from their club/drug careers, thereby maintaining and reproducing their elite status.

\section{Ethnicity and Exclusion in Manchester Clubland}

In analyses of the economic regeneration of the UK in the 1990s, city centres became notable sites for conspicuous consumption, with nightlife seen as at the forefront of the development of new '24 hour party cities' and club promoters positioned as 'subcultural entrepreneurs' within the burgeoning entertainment industry. ${ }^{6,11,25,26}$ Whilst the city has been and remains an enduring metaphor for both diversity and danger, ${ }^{27,28}$ with the association between working class and minority ethnic cultures and 'dangerousness' explored extensivelyboth historically, ${ }^{29-32}$ and in contemporary culture ${ }^{10}$ - such economic regeneration has perpetuated and reinforced pre-existing exclusionary processes resulting in some forms of music and some customers not having been welcomed so readily to the ' 24 hour party'.

In terms of formal processes of regulation, Böse's study of Manchester nightlife showed how selective policing and racial discrimination impacted disproportionately on marginalised groups. She describes how minority ethnic populations were excluded from Manchester city centre clubs in the 1970s and 1980s and pushed into inner city ghettoes for both residential and leisure purposes, whose local facilities lacked the quality, glamour or appeal of city centre venues. ${ }^{6,28}$ Talbot and Böse, in their combined studies of London and Manchester, subsequently describe how, by the 1990s, new forms of discriminatory governance had emerged, wherein "black cultural spaces" were "subject to a process of exclusion" from "the new playgrounds of the night-time economy". ${ }^{33}$ Böse notes that Manchester, a city whose population is over $15 \%$ non-white, continues to be renowned for creative cultural enterprises mostly produced and consumed by the white population. Such enterprises therefore fail to reflect the full range of contemporary urban experiences.

Kirby explored the exclusion from the late-1990s Manchester EDM scene of two UK garage-derived music genres called grime and niche (or bassline). ${ }^{34}$ In trying to understand how some musical forms of black origin ${ }^{b}$ such as grime and niche have been so effectively suppressed within such a racially diverse city, Kirby argues that it was 
y el niche, de una ciudad con tanta diversidad racial, Kirby afirma que la importancia concedida a la cultura de bandas urbanas, especialmente por la Policia del Gran Manchester, dio lugar a "ciertas consecuencias sociales problemáticas en términos de represión cultural, exclusión y censura» ${ }^{34}$. Esta tensa relación entre los supuestos problemas con las bandas, los reglamentos policiales y la vida nocturna de Manchester también ha sido estudiada por Haslam ${ }^{26}$. Los estudios sobre la reglamentación de los locales de ocio y el espacio público en el ámbito de la vida nocturna de Hadfield y sus colegas se han centrado en cambio en la gestión y seguridad de los establecimientos ${ }^{11,17,18}$, y en fechas más recientes en las Asociaciones locales contra la Delincuencia y los Disturbios, así como en redes más amplias dedicadas al gobierno de la ciudad y a su relación con el consumo de alcohol y drogas ${ }^{35}$.

Es interesante resaltar que, si bien Birmingham es una ciudad inglesa con similar diversidad racial, ha sido menor que en Manchester el impacto de la cultura de las bandas y los problemas relacionados con las armas durante tres décadas de vida nocturna con mezcla racial, desde la década de 1970; con un floreciente mundillo reggae y el surgimiento del movimiento Two Tone, a principios de los años 90 los ambientes de fiestas rave con música jungle y hardcore adoptaron un forma distinta y menos excluyente en los Midlands en comparación con el noroeste, como veremos más adelante ${ }^{15,36,37}$. La gentrificación del mundo de las discotecas de Manchester, junto con el nuevo desarrollo del centro de ciudad, hizo que se concediese cada vez mayor importancia al mercado de los jóvenes profesionales y los estudiantes ricos y blancos, en detrimento de las minorias étnicas, la clase obrera y la comunidades locales de rentas más bajas, como demuestra el hecho de que la mayoria de las fiestas de discotecas se suspendiesen durante las vacaciones estudiantiles. Como sostiene Kirby sobre Manchester: "Gran parte del interés del sector de las discotecas se dirige al público estudiantil o a la generalidad. Hay poca oferta de música contemporánea de origen negro dirigida a la comunidad negra, la clase obrera y los sectores pobres urbanos" ${ }^{34, c}$. Böse expresa sentimientos parecidos al describir las industrias culturales creativas de la ciudad como uredes de chicos blancos ${ }^{28}$. El punto fundamental de nuestro análisis es que los ambientes de ocio local apoyan procesos diferenciales de exclusión en marcos sociales comparables. En este caso se considera que las ciudades inglesas de Manchester y Birmingham tienen raices musicales, culturales e históricas

\footnotetext{
de Gran Bretaña formó su propia identidad basándose en la estrecha relación de Gran Bretaña con el Caribe, sobre todo con Jamaican, y que el hip hop estadounidense también se basa en las letras de las rápidas pláticas del reggae jamaicano. Kirby afirma que "describir estilos de música popular... como "música de origen negro"... equivale a reconocer las raices estilisticas del género en la música negra" ${ }^{34}$ p.13-14 , mientras que los que hacen y escuchan música negra son «una generación de jóvenes de diferentes origenes raciales que comparten una cultura común $\|^{34}$ p.15. Por tanto, al describir manifestaciones musicales concretas como "negras" en vez de "urbanas", estamos reconociendo las raices históricas de dicha música y no caracterizando a la audiencia o a los seguidores actuales.

Por ejemplo, un destacado promotor de eventos de drum and bass puso un mensaje en una página web expresando su preocupación ante la violencia potencial o la "actitud" negativa de los clientes de discotecas locales porque se iba a celebrar una sesión de drum and bass en julio, durante las vacaciones de verano de la Universidad, y dijo: "sólo espero que no se exalten los ánimos porque no hay estudiantes". http://www. nwdnb.co.uk/showthread.php?t=40054\&tpage $=3$ [Consultada el 8 de julio de 2009]. Böse hace una observación similar con respecto a las clasificación étnica de las noches de las discotecas de Manchester como "noches negras" o "noches de estudiantes", con la consiguiente escasez de público negro incluso en algunos locales de hip hop de Manchester, que se dirigen a un público blanco de estudiantes "amigos», a través de sus redes de divulgación y de sus estrategias propagandisticas ${ }^{6.432}$.
}

the prioritisation of concerns about the city's gang culture, particularly by Greater Manchester Police, that resulted in "some problematic social consequences in terms of cultural repression, exclusion and censorship". ${ }^{34}$ This tense relationship between perceived gang problems, police regulation and Manchester nightlife has also been explored by Haslam. ${ }^{26}$ Studies on the regulation of leisure venues and public space within the night-time city by Hadfield and colleagues have focussed instead on venue management and security, ${ }^{11,17,18}$ and more recently, local Crime and Disorder Partnerships (CDRPs), as well as the wider networks concerned with urban governance and its relationship to alcohol and drug use. ${ }^{35}$

It is interesting to note that whilst Birmingham is an equally racially diverse English city, it has less notoriety than Manchester for gang culture and gun-related problems, alongside over three decades of racially mixed nightlife from the 1970s onwards: with a thriving reggae scene and the emergence of Two Tone, through to the early-1990s jungle and hardcore rave scenes which took a different and less exclusionary course in the Midlands in comparison to the North West, as discussed below. . $^{1,36,37}$ The gentrification of Manchester clubland in conjunction with the redevelopment of the city centre, by contrast, led to a growing focus on a wealthier, white, student and young professional market, to the detriment of its minority ethnic, working class and lower income local communities, as evident in the majority of club events being suspended during student holiday time. As Kirby summarises, in Manchester: "much of the focus in the clubbing sector is on the student demographic, or on the mainstream (sic). There is little provision for contemporary music of black origin that appeals to the black community, working class, and urban poor". ${ }^{34, c}$ Expressing similar sentiments, Böse describes the City's creative cultural industries as "white boys' networks". ${ }^{28}$ The salient point for our analysis is that local leisure scenes can support differential processes of exclusion across comparable social settings. In this case, the English cities of Manchester and Birmingham are seen to have different musical, cultural and historical roots and to have developed divergent forms of urban governance in relation to the policing and representation of minority

\footnotetext{
drawing on the close relationship that the UK has with the Caribbean, particularly Jamaica", with American hip hop too drawing on Jamaican reggae's fast chatting vocals or toasting. Kirby notes that "describing popular music styles... as 'music of black origin'... acknowledges the genre's stylistic roots in black music", ${ }^{34}$ p.13-14 whilst the people making and listening to black music are "a generation of young people of different racial backgrounds that share a common culture".34 p.15 Thus describing specific musical forms as 'black' rather than 'urban' is an acknowledgement of the historical roots of such music rather than a description of the contemporary audience or following.

For example, a pre-eminent drum and bass events promoter posted a website message expressing concern about potential violence or negative 'attitude' by local club-goers because an upcoming drum and bass event was being held in July, the university summer holidays, saying "just hope its not moody being no students". http://www.nwdnb.co.uk/showthread.php?t=40054\&page $=3$ [Accessed $8^{\text {th }}$ July 2009] Böse makes a similar point regarding the ethnic categorisation of Manchester club nights as 'black nights' or 'student nights' and the consequent scarcity of black people even at some Manchester hip hop club nights which target a white and student 'friends of friends' customer base through their dissemination networks and promotional strategies. ${ }^{6 p .432}$
} 
diferentes y por ello han desarrollado formas divergentes de gobernabilidad urbana en relación al mantenimiento del orden público y la representación de las minorías étnicas, la clase obrera y las comunidades de barrios deprimidos en la vida nocturna. En este artículo afirmamos que se ha desarrollado un proceso de exclusión selectiva en el ambiente jungle/drum and bass (un género de MDE negra), paralelo al identificado por Bose en relación al soul y al género del UK garage, e identificado por Kirby en las músicas grime y niche.

Nuestro objetivo es desmontar los procesos informales de distinción, segmentación y exclusión que caracterizan a las redes de "chicos blancos»" ${ }^{28}$. Al hacerlo pretendemos presentar y definir nociones con derivaciones empiricas sobre las élites culturales y consumistas cuya existencia cuestiona la división entre comercial/«popular» por un lado y "auténticon/underground por otro. En concreto, consideramos la formación de las élites a través de su yuxtaposición con otros grupos sociales en la vida nocturna, demostrando cómo se utilizan procesos informales de exclusión para fundamentar criterios más formales de acceso a los espacios de ocio, entre los que se incluyen algunos de los locales nocturnos y de los ambientes sociales más destacados de Gran Bretaña.

\section{Montando el espectáculo: los obstáculos para acceder a los locales de primera clase}

Los procesos de exclusión se consideran primero en relación al establecimiento de un evento nocturno. Aparte de las reglas formales impuestas por los permisos, la policia, las autoridades locales y los grupos de residentes ${ }^{17}$, funcionan procesos informales que dependen de los protagonistas principales e incluyen a la gerencia de las discotecas, los dueños, los promotores de espectáculos, el personal de seguridad y otras personas en situación de ejercer un poder relativo en la EON. Estos procesos cuestionan la idea de un espíritu PAUR esencial $u$ omnisciente y el alcance de la creatividad radical o de la estética "alternativa" en las discotecas de MDEd. Esas tendencias excluyentes de larga tradición se ven muy bien en Manchester, una ciudad fundamental en los ambientes de MDE rave y posrave de Gran Bretaña, con una conocida variedad de géneros musicales especializados, lo cual resulta aún más llamativo. Estos hechos cuestionan la validez de los discursos de los medios de comunicación, que continúan elogiando el progresismo cultural de Manchester, de modo que:

"Hasta que uno se aleja de la ciudad, es difícil apreciar lo avanzados y progresistas que son los ambientes de discotecas. Aunque los locales estén un poco abandonados, su oferta de sesiones musicales especializadas atrae a un público joven cuyos conocimientos musicales son considerables" ${ }^{38}$.

Manchester desarrolló vigorosos ambientes nocturnos a finales de los años 80 y principios de los 90, en la era "Madchester", con la música baggy alternativa indie/rave (a

d Naturalmente, la utópica imagen PAUR ha sido cuestionada hace mucho tiempo por las autobiografias de primera mano de sus protagonistas, especialmente en lo que respecta a la penetración del crimen organizado en el panorama de la seguridad; réase, por jemp: Anthony W. (1998) Class of 88: The True Acid House Experidad Londres: Virgin Publishing y O'Mahoney, B. (1997) So This Is Ecstasy? Edimburgo: Mainstream Publishing. ethnic, working class and inner city communities in nightlife. This paper argues that a process of selective exclusion has operated in jungle/drum and bass (a black EDM genre) which is parallel to that identified by Bose in relation to soul and UK garage, and identified by Kirby in relation to grime and niche.

Our purpose here is to unpick these informal processes of distinction, segmentation and exclusion that characterise these "white boys' networks". ${ }^{28}$ In so doing, our aim is to present and define empirically-derived notions of both cultural and consumer elites whose existence problematises the commercial/'mainstream' versus 'authentic'/underground divide. More specifically, we consider the framing of elites through their juxtaposition with other social groups in nightlife, showing how informal processes of exclusion are utilised in support of more formal criteria of entry to leisure spaces, including some of the most prominent nightlife venues and social scenes in the UK.

\section{Launching the Night - The obstacles to accessing premium venues}

Processes of exclusion are first considered in relation to the establishment of a club night. Aside from the formal regulation through licensing, police, local authority and local residents' groups, ${ }^{17}$ informal processes operate dependant on the central protagonists who include club management, owners, promoters, security staff and others in positions of relative power in the NTE. Such processes challenge both the notion of an essential or omniscient PLUR ethos and the extent of the radical creativity or 'alternative' aesthetic within EDM clubs ${ }^{d}$ That longstanding exclusionary trends are evident in Manchester, a city at the heart of the UK rave and post-rave EDM scenes, with a renowned diversity of specialist dance genres, is all the more striking. Such concerns perhaps raise questions as to the validity of media discourses that continue to laud Manchester's cultural prowess, wherein:

\begin{abstract}
"Until you travel away from the city, it's difficult to appreciate just how advanced and forward-thinking its clubbing scene is. Though the venues may be dishevelled, its range of specialised music sessions caters for a young audience whose depth of musical knowledge is at times frighteningly sharp." ${ }^{38}$
\end{abstract}

Manchester developed vigorous nightlife scenes in the late-1980s/early-1990s through its 'Madchester' era 'baggy' indie/rave music (by bands such as the Happy Mondays

\footnotetext{
d Of course, the utopian PLUR image has long been challenged by first-hand, behind the scenes autobiographies by such protagonists, particularly in relation to penetration of the security landscape by organised crime, see, for example: Anthony, W. (1998) Class of 88: The True Acid Ho W. (1998) Class of 88. The True Acid House Experience, London: Virgin Publishing and O'Mahoney, B. (1997) So This Is Ecstasy? Edinburgh: Mainstream Publishing.
} 
cargo de grupos como los Happy Mondays y Stone Roses) y la regeneración dinámica de su barrio gay en la zona de Canal Street, que se convirtió en un popular y diversificado lugar de ocio ${ }^{39,40}$. Desde las primeras fiestas sin autorización en almacenes, campos y antros del noroeste de Inglaterra ${ }^{4}$, hasta la mítica discoteca rave Hacienda, propiedad del dueño del sello discográfico Factory, Tony Wilson, y del famoso grupo indie New Order, Manchester estuvo en la vanguardia de la revolución de la MDE, inmortalizada en la película 24 Hours Party Peoplee. Esta base sirvió de nexo para actividades culturales y económicas que jugaron un papel esencial en la reconstrucción y regeneración de Manchester y otras muchas ciudades británicas afectadas por la crisis industrial; dicho fenómeno se ha denominado renacimientos urbano $0^{41,42}$.

El misterio fue entonces cómo géneros de MDE negra como el jungle -surgido en Londres a finales de 1992, con un fuerte arraigo en el sureste y en los Midlands y descrito "como el primer estilo musical negro genuinamente británico, multirracial y muy influyente en los estilos posteriores de música dance británica» ${ }^{34}$ - estuvieron tan marginados en una ciudad con la diversidad étnica de Manchester, en contraste con los florecientes ambientes de MDE desde los primeros tiempos del acid house y el rave. Sin duda, ciertas manifestaciones de MDE negra disfrutan de un atractivo estético y de un capital (sub) cultural que las califica de "guays", pero han sido depuradas para los clientes blancos y los estudiantes: los primeros ambientes discotequeros de la música house de Chicago y el techno de Detroit, cuyas raíces se encuentran en la diáspora africano/caribeña, son ejemplos bien claros de este fenómeno. Por ejemplo, en el drum and bass el éxito comercial del grupo australiano (blanco) Pendulum coincidió con su alejamiento de las sesiones de disc jockeys y su acercamiento a la música en directo, adoptando un formato de grupo más tradicional y la música dance con rasgos de rock duro para atraer al público blanco.

A nuestro modo de ver el tema de la etnicidad ocupa el primer plano cuando, no sólo un número significativo de participantes sino también de seguidores de un género determinado, se identifican como minoría étnica. De modo similar, otros géneros de MDE como el hardcore rave de principios de los 90, el happy hardcore de mediados de los 90, y la música niche/bassline actual se excluyeron/se excluyen del centro de la ciudad de Manchester y del West End londinense en parte porque se dirigen a elementos "brutos» de clase trabajadora, rentas bajas y a audiencias de menos de 18 años, que también se consideran "problemáticas" en ciertos aspectos. Como hemos observado antes, no ocurre lo mismo en todas partes, especialmente en los Midlands.

Una entrevista realizada para este estudio a un conocido DJ de música jungle/drum and bass y promotor de Manchester en su casa en marzo de 2009 por uno de los autores proporciona más material de reflexión con vistas al debate. Presente en estos ambientes desde el principio, Jamac (su apodo de DJ) nació en Moss Side, en una familia jamaicana, y en la actualidad es profesor de tecnología musical. Jamac

\footnotetext{
La película 24 Hours Party People, (2002), dirigida por Michael Winderbottom y protagonizada por Steve Coogan en el papel de Tony Wilson, narra la historia de Fac 51 Hacienda, la discoteca y establecimiento musical abierto desde 1982 a 1997.
}

and Stone Roses) and the dynamic regeneration of its Gay Village around the Canal Street area, which proved to be a popular crossover leisure destination. ${ }^{39,40}$ From some of the earliest unlicensed raves in warehouses, fields and caves around the north west of England, ${ }^{4}$ to the iconic rave club, the Haçienda, owned by Factory record label owner Tony Wilson and internationally renowned indie band New Order, Manchester was at the forefront of the EDM revolution immortalised in the film '24 Hour Party People'. Moreover, this proved to be a nexus of cultural and economic activity that played a key role in the repackaging and regeneration of Manchester and many of Britain's other de-industrialised cities; part of what became known as an urban renaissance. ${ }^{41,42}$

The puzzle then, was how black EDM genres such as jungle - emerging in London in late-1992, developing a strong South East and Midlands base and described "as the first truly original British black music style, as multi racial, and as influencing the UK dance music styles that followed it"34 - could be so marginalised in an ethnically diverse city such as Manchester, with otherwise thriving EDM scenes sustained since the earliest days of acid house and rave. Of course, certain forms of black EDM have aesthetic appeal and (sub)cultural capital as 'cool', yet have been sanitised for white club-goers and students: the early Chicago house and Detroit techno club scenes, whose roots also lay in the African/Caribbean diaspora, are prime examples of this. For example, in drum and bass, the commercial success of (white) Australian act Pendulum came alongside their move from DJ sets to live music, shifting to a more traditional band format and increasingly heavy rock-influenced dance music of appeal to white audiences.

The issue of ethnicity becomes salient, we argue, when not only significant numbers of participants but also followers of a particular genre are identified as predominately minority ethnic. Similarly, other EDM genres such as early-1990s hardcore rave, mid-late 1990s happy hardcore and contemporary niche/bassline were/are also excluded from Manchester city centre and London's West End partly because of their appeal to 'rough' elements of working class, lower income and under-18s populations ie. populations that are also seen as 'troublesome' in some way. As noted above, this has not always been the case elsewhere, particularly in the Midlands.

A case study interview with a well known Manchester jungle/drum and bass DJ and promoter at his home in March 2009 by one of the authors provides further reflection on this debate. Active in these scenes since their inception, Jamac (his DJ moniker) was born in Moss Side to Jamaican parents and is a music technology lecturer by day.

\footnotetext{
The film 24 Hour Party People, (2002), directed by Michael Winderbottom and starring Steve Coogan as Tony Wilson, told the story of Fac 51 Haçienda, the nightclub and music venue open from 1982-1997.
} 
explicó todos los obstáculos que había tenido que superar para establecer un buen espectáculo de jungle/drum and bass en Manchester a mediados de los 90. Tras chocar con impedimentos de diferente tipo, montó Guidance, un espectáculo mensual que duró desde 1996 a 1999, ganó el premio Club Night de la revista City Life de Manchester en 1999 y apareció en la emisora de radio nacional BBC Radio 1. Sin embargo, para presentar su espectáculo en el prestigioso local Sankey's Soap ${ }^{\dagger}$ del centro de la ciudad, Jamac dijo que la gerencia del mismo le había exigido que organizase primero una sesión de ensayo en un local menos prestigioso y que colaborase con un DJ blanco"

"En el Manchester de esa época un chico negro lo tenía difícil para organizar espectáculos nocturnos; preferían a caucásicos... Era lo que ocurría con el soul y con esas cosas, que no se presentaban en la ciudad salvo en ocasiones excepcionales. Guidance fue idea mía, pero necesitaba un DJX [un DJ de drum and bass blanco de fama internacional] para sacarla adelanten.

"Organizar la primera sesión fue bastante laborioso. Fui a Sankeys y, debido al carácter de la música y de sus seguidores, habia que contar con matones y todo eso... asi que el director de Sankeys nos dijo que teníamos que montar una sesión de drum and bass durante un año y, si no ocurría nada malo, podíamos hacerla en Sankeys. Asi que probamos en el Venue A de Whitworth Street, frente al Hacienda, con capacidad para 100 ó 150 personas, durante un año y luego conseguimos presentarnos en Sankeys. Queríamos Sankeys por su prestigio».

Sin embargo, la mayor discoteca de Manchester en la década de 1990, la icónica Hacienda, "fuerza motriz y centro simbólico de Mad-Chester ${ }^{33}$, se consideraba inalcanzable no sólo por la postura de los propietarios, sino porque también el personal de seguridad decidía quien entraba y el género de música que se ofrecía:

"El Hacienda era aún mas inabordable que Sankeys... por gente como Tony Wilson. A Tony Wilson no le gustan los negros ${ }^{\text {h. No }}$

\footnotetext{
Sankeys Soap, reformada y rebautizada con el nombre de Sankeys en 2006, es la discoteca más antigua de Manchester y una de las más antiguas de Gran Bretaña abierta en 1994 en el bicentenario Beehive Mill. En 2008 los DJ la votaron como la tercera mejor discoteca de Gran Bretaña y la 17 a del mundo. Considerada la "capital de los "juerguistas" (Manchester Evening News, 2007, La historia de Sankeys Soap para todos, 10 de febrero, http://www.manchestereveningnews.co.uk/ news/s/235/235755_sankeys_soap_story_for_all_to_see.html [Consultada el 30 de junio de 2009]), recientemente ha celebrado su 15 aniversario.
}

g Tras conseguir que la dirección acepte un espectáculo, existe otra jerarquia que abarca la priorización de las noches de primera para eventos selectos. Las noches de Guidance se celebraban los jueves en Sankeys Soap y nunca obtuvieron las disputadas noches de los viernes y los sábados, reservadas para sesiones de MDE en las que se presentaban variaciones de música house y se dirigian a clientes de diferente perfil demográfico y "nivel superior». El propio Jamac comentó irónicamente que se habia permitido al fin un espectáculo de drum and bass un viernes por la noche en Sankeys en 2009 porque uno de los organizadores pertenecia a "aristocracia" de los clubs de Manchester, pues era hijo del difunto Tony Wilson.

h Phil Kirby, profesor de música, músico y dueño de un estudio de grabación, con presencia en la escena musical de Manchester, sugirió una perspectiva un poco distinta sobre Tony Wilson, el Hacienda y las cuestiones de la etnicidad y la exclusión: "Wilson no era racista, pero por conversaciones [que tuve] con él, comprendi que no "entendia" ciertos estilos de música negra... lo cual inclinaba su gusto hacia lo que Factory ofrecia entonces. No debe olvidarse que uno de los primeros socios de la empresa es mestizo y el gerente de la barra del Hacienda durante muchos años fue negro, como el DJ principal y el primer jefe de los porteros... Hay que matizar las observaciones de Jamac sobre su propio espectáculo frente al del Hacienda con respecto a que su espectáculo se clausuró tras un incidente, mientras que el Hac siguió adelante a pesar de todo de tipo de manifestaciones violentas: el Hacienda pertenecía a sus dueños, no siempre tenian promotores independientes, y cuando los tenían colaboraban estrechamente con ellos. Por tanto, su relación con los espectáculos que ofrecia el local eran muy distintas a las de un club que trabajaba exclusivamente con promotores externos. Si surgía un problema, eran ellos los que tenian que solucionarlo con las autoridades y se jugaban más.. Un local que no monta sus propios espectáculos, vela mucho más por la seguidad y no va a ariesgar su licencia por cuestiones musicales.. Los problemas que los clubs de Manchester tuvieron a finales de los 80 y durante los 90 surgieron porque los accesos estaban controlados por gente relacionada con las bandas. El
Jamac looked back at the obstacles he had overcome in order to establish a successful jungle/drum and bass night in mid-1990s Manchester. After obstruction from various sources, he finally set up Guidance, a monthly night which ran from 1996 to 1999, won Club Night of the Year in Manchester's City Life magazine in 1999 and was featured on national public broadcasting radio station BBC Radio 1. However, in order to launch his event at the prestigious city centre dance venue Sankey's Soap, ${ }^{\dagger}$ Jamac explained how he was asked by the club management to run a trial night at a less prestigious venue first and to go into partnership with a white DJ:9

"In Manchester at that time it was hard for any black lad who wanted to put on a night, they had to have a Caucasian person to put on a night with... That was true for soul music, any stuff like that, you wouldn't get in town except on one-off occasions. Guidance was my idea but I needed DJ X [an internationally renowned white drum and bass DJ] to come on board too."

"Even getting the first night was a bit of a chore. I went to Sankeys and, cos of the nature of the music and the people that followed the music, you've got your villains and all that... so the manager of Sankeys said we had to put on a drum and bass night for a year and if nothing happened you can put one on at Sankeys. So we did IQ at Venue A on Whitworth Street opposite the Haçienda, holds 100-150, for about a year and that's how we got Sankeys. We just wanted Sankeys, cos of its stature."

However, the biggest dance club in 1990s Manchester, the iconic Haçienda - "the driving force and symbolic centre of 'Mad-Chester'" 33 - was considered unattainable because, not only the owners, but also the security staff decided both those who entered the club and also the genre of EDM played there:

"The Haçienda we thought was a bigger challenge than Sankeys... the people like Tony Wilson. I know Tony Wilson don't like black people. 'Look at his record label, there was also young

Sankeys Soap, renovated and renamed Sankeys in 2006, is the oldest dance club in Manchester and one of the oldest in the UK, opened in 1994 inside the 200 year old Beehive Mill. In 2008 it was voted by DJs the $3^{\text {rd }}$ best nightclub in the UK and $17^{\text {th }}$ best nightclub in the world. Considered by some to be the "ravers' capital" (Manchester Evening News, 2007, Sankeys Soap story for all to see, $10^{\text {th }}$ February, http://www.manchestereveningnews.co.uk/news/s/235/235755_sankeys_soap story_for_all_to_see.html [Accessed 30 ${ }^{\text {th }}$ June 2009]), it recently celebrated its $15^{\text {th }}$ anniversary.

Once getting management to agree to a night, a further hierarchy exists regarding the prioritisation of premium nights for the selected dance event. So Guidance the prioritisation of premium nights for the selected dance event. So Guidance
nights occurred on Thursdays at Sankeys Soap and never obtained the premium Friday and Saturday night slots which were reserved for EDM events playing variations of house music, drawing in a different demographic of 'higher end' customers. Indeed, Jamac noted dryly that a drum and bass night had (finally) been allowed to host a Friday night at Sankeys in 2009, but only because one of the promoters was of Manchester club 'royalty', his father being the late Tony Wilson.

$h$ Phil Kirby, a music lecturer, musician and recording studio owner involved in the Manchester music scene, suggested a slightly different perspective on Tony Wilson the Haçienda and issues of ethnicity and exclusion: "Wilson wasn't racist, but from conversations [I had] with him he didn't 'get' certain black music styles... which then predisposed his taste towards the kind of stuff Factory put out. Bear in mind one of the label's original partners is mixed race and the long-term Haçienda bar manager was black, as was the original main DJ and so was the first head doorman. To balance Jamac's observations on his own night versus the Haçienda's, regarding the fact that his night closed after one incident, and the Haç seemed to soldier on through all kinds of violent madness: the Haçienda belonged to the owners and they didn't use independent promoters all the time, and worked with them closely when they did. So they had a different relationship to the events that occurred in the venue than a club exclusively using outside promoters. Any trouble was their responsibility to deal with in regard to the authorities and there was more at stake. A venue that doesn't put its own events on will tend to play it a lot safer, as they won't generally risk their licence for a music policy... The problems the Manchester won't generally risk their licence for a music policy... The problems the Manchester
clubs had in the late 1980s and 90s was that the doors were all run by gang-related crews. The Doorsafe scheme has addressed this to a degree, but the fact that 
hay más que mirar su sello discográfico: estaban surgiendo chicos negros, no sólo chicos blancos, y era un sello independiente. Conozco a gente que conoció a Tony Wilson. En aquel momento estaban todos los de Salford porque controlaban la puerta [una famosa banda blanca, de la cercana ciudad de Salford, controlaba la seguridad del Hacienda]. Habría sido incómodo, no sólo para nosotros, sino para todo el engranaje. La ciudad estaba dividida; por una parte Cheetham Hill [una banda de los barrios degradados de Manchester], por otra el centro de Salford [una banda de Salford], y por otra Moss Side [una banda de las barriadas humildes de Manchester]. Por tanto, al pensar en un evento habia que tener en cuenta esas cosas. La música drum and bass era primordialmente negra, y por tanto resultaba inconcebible en el Hacienda con una banda blanca de Salford controlando las puertas, porque iba sobre todo gente Salford. Sabían lo que llevaba consigo la música. En aquella época el drum and bass no era música de estudiantes, sino música urban"..

Jamac afirmó que al excluir la MDE negra y a sus seguidores, "el Hacienda era al fin y al cabo un club elitista". La ironía estriba en que su dueño, Tony Wilson, alcanzó fama como empresario innovador y dispuesto a asumir riesgos culturales, personalidad de los medios de comunicación y propietario de discos Factory, sello que según Talbot propició «la normalización de la cultura alternativa dentro de las estrategias de regeneración urbana ${ }^{10}$. Y así, en la base del legendario ambiente rave "alternativo" de Manchester, hubo procesos de exclusión informales que provocaron un elitismo cultural.

El establecimiento y continuidad de cualquier discoteca depende en parte de su viabilidad comercial. Las discotecas del West End londinense, que no suelen repartir sus beneficios con promotores externos, aseguran dicha viabilidad a través del alto precio de las entradas, la venta de bebidas y un precio fijo por ocupar una mesa. Por ejemplo, en la carta de $M o^{*}$ vida hay botellas de champán que van desde las 85 a las 6.000 libras esterlinas, botellas de vodka de140€ a $330 €$ whiskys de $14 €$ a $260 €$, cócteles de $9 €$, chupitos a $6 €$, cigarros puros entre $20 €$ y $30 €$ la pieza, y cajetillas de tabaco a $7 €$. Muchos productos de marca se pueden comprar a un precio mucho menor en un supermercado; los que ocupan mesas reservadas, deben pagar un extra del 15\% por el servicio. El cambio de las bebidas pedidas en el bar se devuelve en una bandeja de plata, y es de muy mal estilo no dejar propina; la omisión será "castigada" la próxima vez que el cliente vaya al bar, pues el personal no lo atenderá.

Los que reserven mesa deben gastar un mínimo de $100 €$ por cabeza o $600 €$ por mesa, lo cual aún es más caro. Las "mesas VIP" sólo pueden ser reservadas por miembros y el gasto mínimo es de $200 €$ por persona. Las bebidas más populares son el vodka y el champán; éste último representa

lan de seguridad de accesos diseñó este aspecto, pero el hecho de que las pastillas [éxtasis] sean tan baratas en la actualidad significa que el sector no está tan disputado por las bandas. A más de $20 €$ cada pastilla, el margen de beneficio era asombroso en 1987/88, lo cual aceleró las "guerras de puertas"... Supongo que cierta visión del ambiente de los clubs de Manchester procede de que el problema de las bandas empezo a reflejarse en las puertas de los clubs y determino el trafico de drogas dentro. En la actualidad los más jóvenes vinculados a las bandas temen entrar en los clubs $y$ meterse en problemas, porque cualquiera que lo desee puede conseguir lo que sea [drogas] antes de sali. Ahora sólo los tontos compras drogas en los clubs, mie que los clubs eran el lugar donde se traficaba con drogas en "los viejos tiempos"». [Correo electrónico privado con el autor, julio de 2009]. black kids coming up, as well as young white kids, it was an independent label. I know people who knew Tony Wilson. Then you had the whole Salford thing cos that was them that ran the door [a notorious local white gang based in the nearby city of Salford controlled the Haçienda door security]. It would've been awkward, not just for us but for the whole cycle of things. The way town was cut up, you had [a gang from the Manchester inner city area of] Cheetham Hill running one side, [a gang from the city of] Salford the city centre, [a gang from the Manchester inner city area of] Moss Side another side. So in thinking about an event you had to think about things like that. When drum and bass hit it was predominantly a black thing so it was a no-no having it at the Haçienda with [a white gang from the city of] Salford on the door, as it would be more than Salford [clubbers] going there. They knew what followed the music. When drum and bass came around it wasn't no student music, it was urban music. It has commercialised into student things now."

Jamac summarised that in its exclusion of black EDM and the clubbers who followed it, "at the end of the day, the Hacienda was an elitist club". The irony of this is that its owner, Tony Wilson, was renowned as an innovative and risk-taking cultural entrepreneur, media personality and owner of Factory records, who Talbot claims facilitated "the normalisation of alternative culture within city regeneration strategies".10 Thus underpinning Manchester's legendary 'alternative' rave scene were informal processes of exclusion resulting in cultural elitism.

The establishment and continued existence of any particular club night in part depends on its financial viability. For clubs in London's West End, which tend not to split their profits by using outside promoters, such viability is ensured by high admission fees, drinks prices and fixed table cover charges. The menu at Mo*vida, for example, includes bottles of champagne from $£ 85-6,000$ pounds sterling; bottles of vodka from $£ 140$ to $£ 330$; whiskeys from $£ 140$ to $£ 260$; cocktails at $£ 9$; shooters at $€ 6$; individual cigars at $£ 20-30$; and packets of cigarettes at $£ 7$. Many of the branded products could be purchased at a fraction of the price in a supermarket; for those seated at reserved tables, an optional 15\% service charge is added to the bill. Change for drinks ordered at the bar come on a silver tray with a receipt; it is extremely bad form not to tip and this omission may be 'punished' on one's next visit to the bar by being ignored by bar staff.

For those booking a table there is a minimum-spend requirement of $€ 100$ pounds sterling per head, or $€ 600$ per table, whichever is greater. 'VIP tables' may only be booked by members and have a $£ 200$ per person minimum spend requirement. The most popular drinks are vodka and

\footnotetext{
[ecstasy] pills are so cheap nowadays means that the sector is not as contested by the gangs. At up to $£ 20$ a pill the potential for profit was awesome circa $1987 / 88$ which accelerated the 'door wars'... I suppose one way of looking at the Manchester club scene is that the gang problem was originally visible on the doors of the clubs, and controlled the drug dealing within. Now it's a fear of the younger gang-related kids getting in the clubs and kicking off [causing trouble], as anyone with an inclination can score whatever [drugs] before they go out. Only numpties [idiots] buy drugs in a club nowadays, whereas clubs were the locus of club-drug dealing in 'ye olden days'." [Private email communication with author, July 2009]
} 
más del 30\% de las consumiciones del club. Como se lee en la prensa del sector de la industria del ocio:

"En locales como The Cuckoo Club, The Wardour, o Mo*vida no es raro que un cliente se gaste $30.000 £$ o más en una sola noche. $O$ en una sola botella en el lugar de boga Crystal, en Wells Street, donde Orlando Bloom es uno de los selectos clientes que han pedido una botella de champán Louis Roderer Cristal tamaño Matusalén de $30.000 £^{43}$ ».

Los empleados de las discotecas del West End Iondinense afirman que no es raro «recaudar más de $250.000 \mathrm{f}$ en la barra durante la primera quincena ${ }^{44}$, pero en las discotecas de nivel medio de Manchester las condiciones económicas son mucho más inestables. El reto consiste en fijar un precio de entrada apropiado para compensar o reforzar los beneficios de la barra. Hay que buscar la forma de no disparar el precio, excluyendo con ello a posibles clientes de escasos medios aficionados a la música MDE. El contraste con las discotecas de West End, en las que la política de precios busca excluir deliberadamente a los grupos de rentas más bajas en un contexto en el que la demanda de espacios de ocio nocturno supera la oferta, es muy fuerte. Resulta significativo que uno de los establecimientos incluidos en una serie de estudios recientes sobre las discotecas de Manchester, realizados por uno de los autores, cerrase inesperadamente cuando se estaba realizando el trabajo de campo debido a la bajísima recaudación de la barra, que hizo que la discoteca fuese económicamente inviable para sus propietarios. Sin duda, se debió en parte al intenso consumo de drogas ilegales además 0 , en lugar de, alcohol, como demuestran los resultados del estudio ${ }^{13}$. Para los promotores, cuyos beneficios procedian fundamentalmente de las entradas y no tanto de la recaudación de la barra, el consumo (o no consumo) de alcohol era menos preocupante.

Un segundo motivo básico para el cierre de discotecas son los posibles riesgos o los incidentes reales. Hay abundante información sobre los enfrentamientos entre la gerencia y el personal del Hacienda, el equipo de seguridad relacionado con las bandas de Salford y los alborotadores locales ${ }^{26,42}$. Estos problemas se extendieron durante la década de 1990, hasta que el club acabó por cerrar sus puertas en 1997. Otras discotecas duraron menos. Por ejemplo, el antedicho espectáculo de drum and bass, Guidance, cerró después de un violento incidente que coincidió con una relajación de sus rígidas medidas de seguridad, como explica su promotor Jamac:

"[La banda de] Cheetham Hill controlaba las puertas de Sankeys. Cuando nació Guidance, lo consideraron un punto de referencia. Nunca tuvimos problemas en Sankeys. Los problemas empezaron cuando Sankeys cerró y fuimos al Venue B porque el personal de puertas no era tan duro [como la banda de Cheetham Hill]. Creo que bastaba con que mirases de determinada manera a los porteros del Venue B para que te dejasen entrar. En Sankeys no entraba nadie sin pagar a menos que estuviese en la lista de invitados. Es una cosa típica de Manchester [tratar de entrar sin pagar la entrada ]. En Londres no funciona asím.

Según Jamac su espectáculo de drum and bass «no languideció, sino que lo eliminaron». Hubo un incidente violento, y no le dieron una segunda oportunidad: champagne, with the latter comprising over $30 \%$ of the club's takings. As noted by the leisure industry trade press:

"At venues like The Cuckoo Club, The Wardour, or Mo*vida, it's not unheard of for a customer to spend $£ 30 \mathrm{k}$ or more on a single night. Or on a single bottle, at current Wells St. hotspot, Crystal - where Orlando Bloom is one of a select few guests to have ordered the $£ 30,000$ Louis Roderer Cristal Methuselah bottle of champagne. ${ }^{\text {" }} 3$

Whilst reports of London West End night club operators "taking $£ 250,000$ over the bar in the first fortnight of trading" are not uncommon, ${ }^{44}$ for mid-range Manchester dance clubs economic conditions are significantly more unstable. The challenge is to fix an entrance charge appropriately to offset or bolster whatever the bar profits might be. This must be calculated so as to avoid out-pricing, and therefore excluding, potential customers of more limited means who are amongst the audience for EDM. The contrast with West End night clubs - wherein the pricing policy is intended in part to deliberately deter lower income groups, in a context where demand for night-time leisure space outstrips supply - is stark. It is salient that the leisure venue used for a series of recent Manchester dance club surveys conducted by one of the authors unexpectedly closed down in the midst of the fieldwork due to unsustainably low bar takings which rendered the club economically unviable for its management. This was no doubt due, in part, to the prolific consumption of illegal drugs as well as, or instead of alcohol, as evidenced in the survey findings. ${ }^{13}$ For the club promoters, whose profits came predominantly from entrance charges rather than bar profits, the consumption of alcohol (or lack of it) was of less concern.

A second key reason for the closure of established club nights relates to perceived risk or actual incidents of disorder. The ongoing altercations between the Haçienda's management and staff, the club's Salford gang-affiliated security team, and local trouble makers have been exhaustively documented. ${ }^{26,42}$ These problems continued throughout the 1990s until the club finally closed its doors in 1997. Other club nights had less leeway. The aforementioned drum and bass night Guidance, for instance, closed after just one violent incident which coincided with a slippage in its usually tight security, as its promoter Jamac explains:

"Cheetham Hill [gang] ran the doors at Sankeys. When Guidance came about they looked at that as the benchmark. We never had no trouble at Sankeys. The trouble started when Sankeys closed down and we went to Venue $B$ cos the doorstaff wasn't as tight [as the Cheetham Hill gang]. For me, the doorstaff at Venue $B$, you only had to look a certain way for them to let you in. At Sankeys you couldn't get in without paying unless you were on the guest list. That's a Manchester thing [trying to gain entry without paying the admission charge]. You couldn't get away with that in London."

In Jamac's view, his drum and bass night "didn't fade away, it got took away". Once one violent incident had occurred, he was not given a second chance:

"The last one [Guidance night] got shut down cos of violence ... and that was the end of Guidance. It was always on a tenterhook 
"El último [espectáculo de Guidance] se clausuró debido a la violencia... y ése fue el final de Guidance. De todas formas, el ambiente de drum and bass de Manchester siempre habia pendido de un hilo. Seguramente porque conocían al tipo de público que lo seguía. La oposición a que se celebrase un espectáculo de drum and bass en Manchester no tenía que ver con la música, sino con los seguidores de la misman.

Y así, no sólo la policía, los permisos y las autoridades locales ${ }^{14}$, sino también la gerencia de las discotecas y el personal de seguridad, utilizaron el "gangsterismo" para legitimar la marginación de los ambientes de MDE de Manchester, con la "lógica» de que la música negra atrae al público «conflictivo" y provoca problemas ${ }^{45}$, una lógica que se aplicó a las promociones de drum and bass de Jamac y a una serie de espectáculos de música negra:

"El reggae se mantuvo apartado del centro de la ciudad. Ocurre lo mismo con la música grime, los ambiente niche y cualquier música negra. En cuanto hay demasiados negros en un local del centro, se considera un problema. Al menos en Manchestern.

La "solución» al problema de las "bandas" en Manchester fue que las discotecas de alto nivel impusiesen una política musical que disuadiese a las minorias étnicas y a los grupos de clase obrera. Se suponía que eso, junto con los códigos de vestuario que analizaremos más adelante, reducia el riesgo de problemas al utilizar la música como táctica de exclusión, forma de control de la multitud y discriminación indirecta. Estos procesos tienen una larga historia y se basan, aunque también van mucho más allá, en los problemas creados por las bandas, las armas y las drogas en las discotecas de Manchester desde principios a mediados de la década de $1990^{46}$. La exclusión de ciertos géneros de MDE negra de las discotecas del centro de Manchester continúa en la actualidad, hasta el punto de que un periódico nacional se quejó de que el Festival Internacional de Manchester de 2009, "sin dubstep, drum'n'bass ni hip-hop, no representa el verdadero ambiente musical del Manchester actual, un fenómeno eternamente joven y revitalizador ${ }^{47}$.

La localización espacial de las discotecas es otro indicio de esos procesos de inclusión y exclusión. Talbot indica que los grupos excluidos no se pueden constreñir por completo, pero que tienden a congregarse en "zonas marginales", espacios identificados por Chatterton y Hollands como los márgenes residuales y resistentes de la ciudad ${ }^{20}$. Ese desplazamiento y contención sirven para minimizar la visibilidad y movilidad de grupos "problemáticos» ante el grueso de la sociedad, limitando así la percepción del riesgo de delincuencia y disturbios en el centro urbano. Estos procesos tienen tres directrices principales: en primer lugar, la discriminación formal excluyente de las autoridades que conceden los permisos; en segundo lugar, los procesos informales de exclusión que ejercen las jerarquias de las empresas culturales; y en tercer lugar, factores económicos relacionados con el valor de la propiedad de los terrenos que favorecen la ubicación en zonas de bajo precio de actividades menos sólidas económicamente, en las que domina la experimentación social y la creatividad cultural ${ }^{10}$ p.11. En una entrevista en la revista Night, Eric Yu del Breakfast Club, una empresa que controla una serie de discotecas de Londres, dice: anyway, the whole drum and bass scene in Manchester. Probably cos they knew the type of people that followed it. [Opposition to] getting a club night for drum and bass in Manchester was never about the music, it was about the people that followed the music."

Thus not only for police, licensing and local authorities, ${ }_{1}^{14}$ but also for dance club management and security staff, 'gangsterism' was used to legitimate the discouragement of Manchester's black EDM scenes through the 'logic' that black music attracts the 'wrong' crowds and leads to trouble, ${ }^{45}$ a logic which was applied to Jamac's drum and bass promotions and to a range of other black music nights:

"Reggae music was kept away from the city centre. You see it with the grime scene, the niche scene, any black music. As soon as there's too many black people in one place in the city centre it's seen as a problem. In Manchester anyway."

The 'solution' to the perceived 'gangster' problem in Manchester, then, was for high profile dance clubs to have a music policy which discouraged attendance by minority ethnic and working class communities. The assumption was that this - alongside the use of dress codes, discussed below - would reduce the risk of trouble, effectively using music as an exclusionary tactic, a form of crowd control and indirect discrimination. These processes have a long history, incorporating, but also going well beyond the peak of concerns about gangs, guns and drugs within Manchester clubs in the early to mid 1990s. ${ }^{46}$ This exclusion of some black EDM genres from Manchester city centre club cultures continues to the current day, with a national newspaper lamenting of the 2009 Manchester International Festival, that "with no dubstep, drum'n'bass or hip-hop, the lineup still fails to represent Manchester's true contemporary club scene, an ever-youthful and revitalising beast". ${ }^{47}$

The spatial location of club nights, then, is a further indication of such processes of inclusion and exclusion. Talbot suggests that excluded groups cannot be restrained entirely but rather are contained within 'outsider areas', those spaces similarly identified by Chatterton and Hollands as the residual and resistant margins of the city. ${ }^{20}$ This form of displacement and containment serves to minimise the visibility and mobility of 'problem' groups to wider society, thus limiting the perceived risk of criminality and disorder in the urban core. These processes have three main drivers: firstly, exclusionary discrimination by formal licensing authorities; secondly, informal processes of exclusion by established hierarchies of cultural entrepreneurs; and thirdly, economic factors related to land and tenancy values which favour lower cost locations for activities which are less commercially robust and involve social experimentation and cultural creativity..$^{10.11}$ In interview with Night magazine, Eric Yu of The Breakfast Club, a company operating a string of London dance venues comments that:

"A lot of people who want to put dance venues together probably cannot find opportunities - or the money - to do that in the 
"Mucha gente que quiere abrir discotecas no encuentra la ocasión -o el dinero-para hacerlo en las zonas más deseables de Londres y se ven relegados al exterior. En Brixton hay lugares más baratos que permiten ganar dinero a los promotores y empresarios vendiendo cerveza y refrescos, mientras que en el West End dominan las ventas de cócteles y champán. Por eso ya no se sostienen los ambientes de vocación musical, con la excepción de unos cuantos locales»" ${ }^{48}$.

En Manchester la concentración de la MDE negra en los barrios degradados quedó patente en la ubicación de la principal discoteca de música jungle en la zona de Hulme entre principios y mediados de la década de 1990. Jamac observó la falta de presencia policial en el establecimiento, a pesar de que en muchos espectáculos el público disparaba al aire mientras sonaba la músicai. Comparó dicha situación con el mantenimiento del orden público y la violencia de negros contra negros en la zona próxima de Moss Side:

"Les encanta coger el dinero de la gente un día, pero no quieren que se congreguen negros en el mismo sitio todas las semanas. Siempre que no sea en el centro de la ciudad, si tienen una discoteca en Moss Side, los negros pueden matarse entre sí si quieren. En Moss Side los negros se matan y nadie lo investiga".

Como demuestra el estudio de caso anterior, los principales obstáculos para organizar espectáculos de drum and bass en las primeras fiestas urbanas de 24 horas celebradas en Gran Bretaña en la época álgida de la «década de la música dancen no procedieron de la policia ni de las autoridades que otorgaban los permisos, sino de los dueños, gerentes y personal de seguridad de las discotecas del centro de la ciudad, locales icónicos con fama internacional de estar a la vanguardia de la música ravey dance «alternativa».

\section{Ante la puerta - Promociones online}

Dentro de las metrópolis urbanas las variedades musicales y estilísticas dan lugar a diferentes ambientes de ocio ${ }^{49}$, que se manifiestan en lealtades y preferencias en torno a los deportes, los establecimientos de diversión y las actividades sociales. Internet es una vía cada vez más importante para crear y mantener comunidades virtuales a través de páginas web adaptadas a determinadas actividades y gustos lúdicos. Junto con las técnicas publicitarias habituales, los anuncios y promociones en la prensa local y nacional, los carteles en lugares públicos, etc., Internet ofrece páginas web y chats especializados en música/discotecas de MDE a los clientes con gustos afines y "comprometidos" ${ }^{50}$. Los visitantes de las páginas web de discotecas encuentran listas de locales, reciben "invitaciones» electrónicas y manifiestan su interés en acontecimientos concretos. Estos procesos contribuyen a la segmentación de la EON al permitir que los dueños y promotores de las discotecas identifiquen al público de sus espectáculos y se dirijan a clientes concretos. Una forma de

Esto contrasta con el enfoque de la Policia de Merseyside y la protección que dispensó a la mítica discoteca Cream del centro de Liverpool en 1993-4. El local, considerado esencial para la regenera considerado esencial para la regeneraion del centro de esencialmente blanco, contó con vigilancia de policias armados para disuadir a los miembros de las bandas locales. more salubrious parts of London, so they've gravitated outwards. Brixton has places that are lower cost, that allow operators and promoters to make money on people buying beer and soft drinks, whereas in the West End operators are reliant on cocktail and champagne sales. That's why the music-led scene over there, with the exception of a few venues, no longer exists. ${ }^{148}$

In Manchester, the containment of black EDM within the inner city was evident in the location (in the inner city area of Hulme) of the main jungle club in the early to mid1990s. Jamac noted the lack of a police presence at the venue, despite the club being renowned for hosting events where club-goers repeatedly fired guns in the air in time to the musici. He linked this to wider concerns regarding the policing of black-on-black violent crime in the nearby inner city area of Moss Side:

"They're happy to grab your money on a one-off basis but they don't want black people congregating in the same place every week. If it's not in the city centre, if they're having a club down in Moss Side, black people can kill each other out of the city centre. There's black people killing each other in Moss Side and it doesn't get properly investigated."

As the above case study shows, the main obstructions faced in attempting to establish a drum and bass night in the first ' 24 hour party city' in the UK during the height of the 'decade of dance' came not from the police or licensing authorities but from the owners, management and security staff at city centre dance clubs, iconic clubs which became internationally renowned for being at the forefront of the 'alternative' rave and dance club scene.

\section{Before the Door - Online promotions}

Within the urban metropolis, different local leisure scenes are created by musical and stylistic distinctions, ${ }^{49}$ perpetuated by allegiances and preferences around sports, leisure venues, and social activities. The internet is an increasingly important way of creating and maintaining virtual communities through websites tailored to specific leisure time activities and tastes. As well as standard marketing, advertising and promotions in national and local press, public fly postering and so forth, the internet offers specialist EDM club/music websites and chat-rooms for likeminded and "committed" clubbers. ${ }^{50}$ Visitors to clubbing websites can view club listings, receive electronic 'party invitations' and register their interest in specific events. These processes contribute to the segmentation of the NTE by allowing club management and promoters to identify audiences for their events and to target particular customer bases. One way this operates is through the spectacle of

\footnotetext{
This was in stark contrast to the approach adopted by Merseyside Police in protecting the flagship Cream nightclub in Liverpool city centre circa 1993-4. Recognised as essential to the regightch in Liverponl city centre circa 1993-4. Recognised as essential to the regeneration of Liverpool city centre and appealing to a predominantly white audience, the club was provided with guardianship by armed police in order to deter the attention of local gang members.
} 
promocionarse es a través de la publicación de galerias fotográficas online en las que se ve a los clientes in situ en sesiones anteriores.

Las discotecas de alto nivel del West End londinense utilizan las páginas web para anunciar espectáculos y publicar sus criterios de acceso. También permiten que los miembros online se apunten a espectáculos exclusivos, reservados a invitados o de entrada restringida. Las galerías fotográficas cumplen además el objetivo de mostrar la vestimenta, la imagen y los complementos adecuados. La página web www. londonparties.co.uk, dedicada a acontecimientos sociales de la capital británica «impecables y chic», "llenos de deslumbrante glamour y opulencia», "lujo», "estilo y glamour natural», por ejemplo, muestra a clientes atractivos y bien arreglados, que beben champán y posan ante la cámara. Una discoteca que se anuncia en dicha página afirma que "recibe a una nueva súper élite» en "un espacio exclusivo para los derrochadores", que rebosa "abundancia de clase y estilo" junto a "la exquisita esencia del lujo». Se ofrecen todo tipo de detalles sobre los servicios para miembros y para VIP, descripciones de la decoración, la iluminación, los asientos y las variedades de champán que se sirven («neveras llenas de botellas tamaño mágnum, Jéroboam y Matusalén de los mejores champanes del mundo y monumentales botellas de vodka de primera clasen), pero apenas se habla de los DJ ni de los estilos musicales. Los conceptos de las discotecas indican una influencia "exótica" global. Por ejemplo, la carta del Chinawhite's explica que en su decoración "los estilos orientales de Bali, Java y Sumatra se funden con un aire teatral que debe mucho a la influencia del ballet, el teatro y los decorados cinematográficos, lo cual crea un espacio impactante y diferente, con un sorprendente uso del color e ideas nuevas y refrescantes. [El concepto de discoteca] supone una ruptura total con el insulso minimalismo, la omnipresente caja negra o los locales revestidos de mármol de los últimos años; la diferencia es sorprendente y agradable».

En Manchester el sistema de listas de invitados de las discotecas se limita al registro del nombre online antes de un espectáculo concreto para obtener un pequeño descuento en el precio de la entrada, pero en Londres la lista de invitados es discrecional y selectiva. El cliente potencial no sólo debe registrar su nombre online, sino que los porteros y otros miembros del equipo de acceso $u$ "ojeadores" lo someten a un detallado escrutinio cara a cara antes de permitir la entrada en el local. Esta capacidad de excluir por medio de criterios dudosos y subjetivos es característica del modelo de gestión de muchas discotecas del West End londinense ${ }^{18}$.

Las discotecas de Manchester también cuentan con páginas web especializadas en las que promocionan espectáculos, pero en las que se reserva un considerable espacio para hablar de sesiones de DJ pasadas y futuras, la "forma física" de los DJ famosos, los estrenos o mezclas de MDE, los nuevos equipos de sonido/tecnológicos, y cotilleos sobre los subgéneros musicales y la situación de los ambientes de MDE. En una página con guías de ocio los promotores anuncian elencos de DJ y encargados de controles (MC) y colocan imágenes escaneadas de los carteles/folletos de los eventos (que no siempre aparecen en las vallas publicitarias de la ciudad). online photograph galleries showing club-goers in situ at previous events.

For upmarket clubs in London's West End, online party websites are used to advertise upcoming events and specify door policies. They also allow online members to sign up to exclusive, guest-list only, or limited entrance events. Photograph galleries serve the further purpose of illustrating appropriate dress, image and grooming. The website www. londonparties.co.uk, which is dedicated to social scenes in the capital that are "sleek and chic", "all about dazzling glamour and opulence", "luxury", "style and relaxed glamour", for example, shows customers who are attractive and well-groomed, drinking champagne and posing for the camera. One club promoted on the site considers itself to "play host to a new super elite" in "a unique playground for the extravagant" which exudes "an abundance of class and style" alongside "the exquisite essence of luxury". Whilst details of members-only and VIP facilities are provided, alongside descriptions of décor, lighting, seating and varieties of champagne on offer ("fridges brimming with magnificent magnums, jeroboams and Methuselah's of the world's finest champagnes and monumental bottles of premium vodka are displayed"), there are notably few details of DJs and music styles. Club concepts are connotative of an 'exotic', global influence. For example, Chinawhite's menu explains how, in its décor, "the oriental styles of Bali, Java and Sumatra are fused with a theatrical flair that owes much to the influences of ballet, theatre and film sets, creating a space that is dramatic and different, with startling use of colour and refreshing new ideas. It [the club's concept] offers a complete break from the bland minimalism, ubiquitous black box, or marble clad venues of recent years; the difference is both surprising and welcome".

Whilst guest list systems for Manchester dance clubs involve little more than registering one's name online in advance of a particular event in order to obtain a small discount on the standard admission fee, the London party guest list scheme is both discretionary and selective. Not only does a potential customer register their name online but they also then submit to considerable face-to-face scrutiny from door staff and other front-of-house selection staff or 'spotters', before entry to the nightclub is secured. This capacity to exclude through the application of often spurious membership schemes has been intrinsic to the business model of many of London's West End nightclubs. ${ }^{18}$

For the Manchester dance clubs, specialist websites also provide marketing opportunities for forthcoming events, but here a sizable space is dedicated to discussion of past and future DJ sets, the current 'form' of well known DJs, EDM releases or remixes, new technology/sound equipment, and banter about musical sub-genres and the current state of EDM scenes. A listings page allows promoters to post the line ups of DJs and MCs, together with scanned images of the posters/flyers for the event (which may or may not also be fly-posted on hoardings around town). Beneath each listing, website users and regular participants in the local 'scene' 
Debajo de cada elenco, los visitantes de la página web y los habituales de los "ambientes" locales valoran a los DJ, dicen si van a asistir o no y establecen contacto con otros asiduos antes del evento. Por ejemplo, el anuncio de un espectáculo de drum and bass llamado Religion en Sankeys en julio de 2009, comenzó con una lista completa de los DJ y MC contratados para la ocasión en el folleto oficial y un mensaje del promotor animando a los visitantes de la página web a asistir:

"iiiOh sí, colegas!!! ¿Lo pasasteis bien en la fiesta de estreno de Religion? Si no fuiste uno de los 1.400 seguidores que agotaron las entradas, procura no perderte esto... Lo siento por la gente que quiso entrar la última vez y se quedó fuera porque se habian vendido todas las entradas. Os aviso con antelación de que se trata de un acontecimiento de masas. Después de un estreno tan increible, seguro que el éxito se repite... iiiasi que prepárate, consigue una entrada y ven pronto para unirte a nosotros!!!"

Debajo de este mensaje, los visitantes de la página web enviaron comentarios como: "Un buen reparto (-) cuanto más grande mejor" (sic), "Me muero de ganas de veros. Bravo por Oli y los chicos de Religion" y "Tengo que ir como sea, ies demasiado genial para perdérselo!" También hay fotos en este caso, por ejemplo en www.nwdnb.co.uk, aunque son muy distintas a las de las discotecas del West End londinense. No hay copas de champán y poses ante la cámara, sino primeros planos de los DJ en las mesas de mezclas o "fotos en plena acción" de multitudes de animados discotequeros bailando enérgicamente. En esas fotografías destacan los tropeles de discotequeros de marcha, alegres y embriagados, que contrastan radicalmente con los individuos repeinados, pijos y pendientes de la cámara que representan a la élite de las discotecas de Londres.

Muchos visitantes de las páginas web de MDE envían mensajes $y$, aunque su personificación a veces no tiene nada que ver con su verdadera identidad, se conocen en las fiestas, tras concertar citas a través de la web. De ese modo las comunidades virtuales y verdaderas se refuerzan mutuamente (al menos los que tienen acceso a Internet), y las relaciones no sólo se mantienen, sino que se amplian por medio de la identificación con una determinada página web. A los usuarios habituales la comunidad online les ofrece un lugar para plasmar el capital (sub) cultural adquirido a través de una personificación online y de la larga historia del mundo de las discotecas ${ }^{51}$.

Como observó Weber con respecto al ambiente rave de Toronto', el coste económico de frecuentar discotecas conduce a veces a la exclusión de los grupos con ingresos más bajos. En dicho coste se incluye no sólo el precio de la entrada (que oscila de 10 a 15 libras esterlinas en las discotecas de nivel medio de Gran Bretaña hasta 40 libras o más en los eventos puntuales con escenarios múltiples y la actuación de numerosos DJ a lo largo de 12 horas o más), sino también el precio del transporte, las consumiciones, las drogas ilegales, la ropa y los accesorios. Estos condicionantes económicos llevaron a Weber a afirmar que en Toronto "la mayoria de la gente que asiste a fiestas rave pertenece a lo que se define de forma poco precisa como clase median puesto que

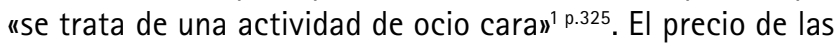

can then appraise the forthcoming DJs, discuss whether or not to attend and make contact with other club-goers in advance of the event. So, for example, the postings for an upcoming drum and bass night, called Religion at Sankeys in July 2009, started with the official flyer providing a full list of all DJs and MCs booked to perform at the event and a message from the promoter encouraging website readers to attend:

"Oh yes people!!! Did you enjoy the Religion launch party??? If you weren't one of the 1,400 bass believers that made it a sell out success then make sure you don't miss out on this one... I am sorry to the people who wanted to rave last time and got turned away because the club had totally sold out. You were warned well in advance that this is a "roadblock event". After such an incredible launch night it will probably be the same again... so fix up, get your ticket sorted and turn up early so you can join us inside!!"

Below this, website regulars posted comments such as "Nice line up (:) shud be large indeedy" (sic); "Can't wait for this. Big up Oli and the Religion crew" and "Gonna have to go to this, it's too huge to miss!!!" Photograph galleries are again prominent, for example, at www.nwdnb.co.uk. Yet the images are quite different to those of London's West End nightclub galleries. There is a notable absence of champagne glasses and camera poses, the more usual content being close ups of DJs on the turntables mixing records, or 'action shots' of crowds of hot clubbers dancing vigorously. Such photographs are notable for throngs of active, animated and intoxicated club-goers, in sharp contrast to the glamorous, posed and composed individuals representing London's clubbing elite.

Many EDM website participants will place regular postings and although their avatar might give few clues as to their real identity, participants also meet at club events, arranged through the website. In this way virtual and actual club communities mutually reinforce one another (for those with access to the internet), meaning that relationships are not only maintained but progress through identification with a particular website. For regular users, the online community provides a stage for the display of (sub) cultural capital acquired through an established online persona and lengthy clubbing history. ${ }^{51}$

As Weber noted in relation to the Toronto rave scene, ${ }^{1}$ the financial costs of clubbing can potentially lead to the exclusion of lower income groups. Such costs include not only the entrance fee (ranging from $£ 10-15$ pounds sterling for mid-market UK dance clubs up to $£ 40$ pounds sterling, or more, for one-off dance events with multiple arenas and many DJ acts, across the course of 12 hours or more), but also include the costs of transport, drinks, illicit drugs, clothing and accessories. Such financial influences prompted Weber to conclude that in Toronto "most people who attend raves come from what was loosely defined as middle class backgrounds" because "raving was recognised as being an expensive leisure activity". 1 p.325 Entrance charges are the most obvious economic method of exclusion and are clearly an exclusionary strategy in West End night clubs, 
entradas es el método de exclusión más directo y una estrategia claramente excluyente en las discotecas del West End, con tarifas mínimas de $20 €$, así como el precio de las consumiciones y el servicio de mesa en el interior. Las entradas de las discotecas de Manchester, por contraste, oscilan entre 10 y $15 €$, incluso menos, con descuentos por "compra anticipada" online varias semanas o meses antes de un evento concreto, que reducen el precio a cinco libras en el momento de escribir este artículo, también para los espectáculos con múltiples $\mathrm{DJ}$. Se pueden obtener reducciones aún mayores comprando las entradas en agencias que aplican una tasa mínima por reserva o solicitando online la inclusión en una "lista de invitados de pago", con lo cual al registrarse para un espectáculo concreto se consigue cierta rebaja en el precio de la entrada (unas dos libras esterlinas). Sin embargo, aparte de la rebaja en el precio de las entradas, el sistema de la lista de invitados de pago ofrece otras ventajas, como una fila separada "de ritmo rápido", no tener que pagar reserva y una mayor probabilidad de entrar en el establecimiento, puesto que el cliente ha mostrado su interés por el espectáculo. En estos ambientes de MDE los clientes que han hecho la reserva online tienen menos problemas para entrar. Sin embargo, hay que conocer la página web en cuestión, seguir el hilo y respetar la etiqueta online (por ejemplo, enviar un mensaje a un promotor concreto) para acceder y suscribirse a dichas listas. De ese modo, el acceso a espectáculos especiales de MDE depende tanto del conocimiento de la cultural local como de la capacidad adquisitiva del consumidor ${ }^{6}$.

Las discotecas de alto nivel del West End también recurren cada vez más a proyectos de suscripción anual y a listas de invitados/pago online para identificar a los clientes con antelación. Sin embargo, figurar en una de esas listas no garantiza la entrada y, al igual que en las discotecas de Manchester, el objetivo no es sólo económico (entradas con descuento), sino tentar al público con la posibilidad de conseguir una entrada y divulgar ideas de escasez y fuerte demanda que contribuyen a fomentar los "rumores» en torno al establecimiento y sus espectáculos. No obstante, hay diferencias esenciales entre los ambientes de MDE de Manchester y el "glamour" de Londres en la forma de comunicarse online los clubs y los clientes. Las páginas web especializadas de MDE/ club pretenden facilitar el diálogo y responder a los mensajes de los clientes, y el moderador sólo censura el material potencialmente ofensivo o insultante. Por contraste, las páginas web londinenses son elaboradas casi en exclusiva por el personal de la web, con pocas o ninguna posibilidad de interacción con los clientes. El contenido destaca el carácter selecto de los clubs y los famosos que han asistido a espectáculos anteriores, ofreciendo a los clientes la posibilidad de asistir a los eventos sociales de la "lista A" y de conocer a los famosos. No hay ambiente humorístico ni de complicidad; tales eventos se presentan como aspiraciones serias, uimportantes", que la gente ha de "esforzarse" por "conocer" y estar al nivel. with typical entrance fees of $£ 20$, as well as the price of drinks and table service once inside. Manchester dance club entrance fees, by comparison, are rarely more than $€ 10$ 15 pounds sterling, and often even less, with 'early bird' discounted tickets available to purchase online several weeks or months before a specific event, reducing the cost to as little as five pounds sterling at the time of writing, even for

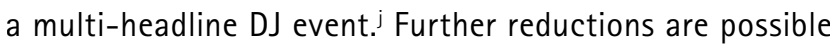
by buying tickets from outlets known to charge a minimal booking fee or by applying to join an online 'paying guest list' whereby registering for a specific club event can result in a slight reduction in the entrance fee (by about two pounds sterling). However, at least equal to the reduced entrance fee, are the other possible advantages of the paying guest list system, such as separate 'fast track' queuing, no booking charge and greater likelihood of gaining entry on the night because the customer has shown commitment to the specific event and entertainment on offer. In such EDM scenes, customers who have pre-booked online usually have little problem gaining entry on the night. However, knowledge of the required website, thread and online etiquette (such as posting to an individual club promoter) are necessary in order to access and subscribe to such guest lists. Thus, entrance to specialist EDM events is as much predicated on local cultural knowledge as on consumer spending power. ${ }^{6}$

Upmarket West End nightclubs also increasingly use annual membership schemes and online payment/guest lists, to identify customers before they arrive. Being named on such guest lists does not guarantee entry, however, and similar to Manchester dance clubs, the purpose is not simply financial (discounted entrance fees) but rather to tempt with the increased possibility of entry and notions of scarcity and demand which help build a 'buzz' around the venue and its events. There are, however, key differences between the Manchester EDM and London 'glamour' scenes in relation to the ways in which clubs and their customers communicate online. Specialist EDM/club websites aim to facilitate dialogue and respond to postings by club-goers, with the moderator only censoring potentially offensive or libellous material. By contrast, the London material is almost exclusively written by website staff with little or no opportunity for interaction with club-goers. Instead the material emphasises the exclusive nature of the clubs and the celebrities who previously attended specific events, holding out the opportunity for club-goers to attend 'A-list' social events and possibly even meet such celebrities. There is little notion of humour or playful engagement, however: these are presented as serious, even 'important' aspirations, toward which one must 'work' through being 'in the know' and of the right calibre.
Por ejemplo, en Oh My God, un espectáculo mensual de drum and bass del centro de Manchester, actuaron cuatro DJ de renombre nacional, además de otros, en julio de 2009. Las entradas adquiridas con antelación www.skiddle.co.uk costaron $5 €$.
For example, at Oh My God, a monthly Manchester city centre drum and bass event four headlining nationally renowned DJs, plus others, played in July 2009. Early bird tickets on www.skiddle.co.uk cost $€ 5$. 


\section{"¿Poco marchoso?» Imagen, entrada y exclusión}

Adaptar la imagen de una discoteca o un evento -a saber, las intenciones, previsiones o aspiraciones de sus creadores- a la de los clientes requiere un complejo sistema de selección, autoselección y exclusión. En términos de estética, las promociones online y las galerías fotográficas proporcionan pistas visuales para adaptar el estilo a las expectativas, como hemos visto anteriormente. Sin embargo, los símbolos visuales más impactantes de inclusión y exclusión se encuentran in situ, y se analizan aquí en lo relativo a la puerta como barrera física, y a la apariencia externa de los clientes, potenciales y reales. La regulación de la entrada y del "trabajo de los porteros" se ha estudiado en detalle en otros lugares, sobre todo en lo que atañe al riesgo de violen$\mathrm{cia}^{52}$. Este artículo se centra en las decisiones discrecionales, que no sólo se basan en señales visuales interpretadas como amenazas, sino también en matices de imagen, aspecto 0 indumentaria que indican o niegan el encaje de determinados clientes en determinados establecimientos. Los aspectos de identidad personal se consideran deseables y constituyen un proceso que sitúa, caracteriza y mantiene la posición social de locales y eventos en los fragmentados ambientes del ocio nocturno.

La grandiosidad y el rebuscado diseño de las entradas de las discotecas del West End contrastan con las modestas puertas de las discotecas del centro de Manchester. En el West End muchos clubs se ubican en edificios prestigiosos, de estilo clásico, con columnas dóricas en la entrada, escaleras de mármol o vestíbulos, e imponentes puertas con placas de bronce en las que el logotipo del club figura con discreta elegancia. Los códigos de indumentaria de estos locales, cuando se especifican, subrayan el estilo, el lujo y el glamour. Por ejemplo, uno de los clubs de www.london.co.uk describe su código de indumentaria como "estrictamente elegante", "no se permite la entrada de cualquier manera", admitimos pantalones vaqueros siempre que sean de marca, pero NO ZAPATILLAS DEPORTIVAS, camisetas desaliñadas, jerseys con capucha, gorras, disfraces (incluyendo vestidos de cumpleaños/tocados)".

A partir de este código de indumentaria los potenciales clientes «entienden" que no sólo se prohibe la entrada a fiestas de despedida de soltero/soltera y de cumpleaños con disfraces, sino también a gente con trajes de fiesta baratos y orejitas de conejo "de broma". Sin embargo, el código de indumentaria suele quedar implícito y no se aplican las normas a rajatabla (ciertas personas son admitidas con ciertos vaqueros y camisetas). En realidad, esto supone un nivel de exclusión añadido, puesto que a los posibles clientes no se les da la oportunidad de alegar que cumplen los requisitos. No decimos con esto que la selección sea arbitraria, sino que los clubs saben qué tipo de cliente quieren admitir, y al tipo de cliente que quieren admitir no hace falta que le digan cómo debe vestirse: lo sabe porque se trata de una élite adinerada, glamurosa, consumista que se encuentra en su medio natural. En consecuencia, la mística de la identificación entre el establecimiento y el cliente se perpetúa y se refuerza.

\section{"Not Funky Enough"? - Image, entrance and exclusion}

To accurately align the image of a club or event - that is, the intentions, visions or aspirations of its creators with those of its customers involves a complex system of selection, self-selection and exclusion. In terms of aesthetics, online promotions and photograph galleries provide visual clues which set the tone in relation to expectations, as discussed above. However, the most dramatic visual symbols of inclusion and exclusion are found in situ, discussed here in relation to the door as a physical barrier, and the physical appearance of customers and potential customers. The regulation of doors and 'door work' has been explored in detail elsewhere, particularly in relation to the risk of potential violence. ${ }^{52}$ This paper is concerned with ways in which such discretional decision making focuses not only upon visual cues as to perceived threat, but also upon nuances of image, appearance or clothing which indicate or foreclose the matching of specific potential club-goers to specific clubs. Here aspects of personal identity are judged desirable or otherwise in a process which allocates, denotes and maintains the social positioning of venues and events across fragmented nightlife scenes.

The grandeur and design consciousness of West End nightclub entrances is in sharp contrast to the unprepossessing doors of Manchester city centre dance clubs. In the West End, many nightclubs are located in prestigious, classically-styled buildings featuring, for example, Doric columns at the entrance, marble steps or lobbies, and imposing doors with brass plates upon which the club's logo is subtly embossed. Dress codes for such venues, where specified, tend to emphasise style, luxury and glamour. For example, one of the clubs on www.london. co.uk specifies its dress code as "strictly smart, 'no effort, no entry', we do allow jeans as long as they are smart, but NO TRAINERS, scruffy T Shirts, hooded jumpers, caps, fancy dress (including birthday garments/head pieces)". From this dress code, potential customers can 'read' that not only will stag/hen parties and birthday groups in fancy dress be refused entry but also those in low budget party clothing such as 'joke' rabbit ears. More often, however, the dress code is implicit and hard and fast rules are not applied (some people may be admitted wearing some jeans and t-shirts). This, in fact, presents a further tier of exclusion, as potential customers are not given the opportunity to argue that they meet any specified requirements. This is not to say that selection is arbitrary, it is rather that the clubs know the type of customer they want to admit and the type of customer they want to admit does not have to be told how to dress, they already know how to dress because they are an affluent, glamorous, consumer elite and this is their playground. Consequently the mystique of venue and customer alike is perpetuated and enhanced.

Similarly, Manchester dance clubs in general make little attempt to entice passing trade to randomly enter 
De modo similar, las discotecas de Manchester en general se preocupan poco de fomentar el comercio de entradas 0 de imponer un acceso aleatorio ${ }^{5,8}$, y prefieren promocionar sesiones de MDE especializadas y dirigidas a seguidores a través de Internet y de otras estrategias publicitarias concretas. Por otro lado, una vez dentro, la mayoría de los clientes no quieren "exhibirse" ante los curiosos. Y por ello los locales prefieren no anunciarse ante todo el mundo. Los clientes entran por puertas oscuras y anónimas que conducen a sótanos, en un proceso que Garrat denominó el descenso a la conejera y al País de las Maravillas ${ }^{53}$. Estos clubs son lugares bastante reservados de retiro y evasión, a los que acuden quienes buscan sitios de ocio conocidos sólo por unos cuantos. A veces las puertas ni siquiera tienen letreros, y la existencia de un club no se nota hasta última hora de la noche, cuando se forman colas en la calle.

Vemos que tanto las discotecas del centro de Manchester que se dirigen a las élites culturales como los clubs de West End que atraen a las élites consumistas procuran disuadir al cliente ocasional que sólo pretende beber la última copa o bailar un poco. La selección de las personas que desean entrar constituye un problema para los gerentes de los establecimientos. En una serie de locales la cola se organiza o manipula por diferentes motivos. Las colas de clientes que esperan entrar se utilizan a veces como márketin, señal de la popularidad, el prestigio o el poco valor del local ante los transeúntes. Por ello, al personal de la puerta se le ordena a veces que haga esperar a los clientes, aunque no sea necesario, sobre todo los fines de semana ${ }^{54}$. La existencia de una cola significa que porteros vigilantes y profesionales tardan cierto tiempo en registrar y seleccionar a los clientes potenciales, además de servir de gesto que indica su autoridad sobre los mismos: en el establecimiento no entra nadie sin el permiso de los porteros. El tiempo de espera permite a los porteros valorar el nivel de embriaguez y posible conflictividad de los clientes que guardan cola, asi como observar lo adecuado de la vestimenta y aspecto de dichas personas.

En la discrecionalidad del personal de puertas, la gerencia de los establecimientos y los organizadores de eventos influyen complejos procesos de exclusión, igual que en los "ojeadores" externos que discriminan a los clientes deseables de los indeseables. En este punto es esencial el código indumentario que, a primera vista, resulta muy esclarecedor. Por ejemplo, el código indumentario de una discoteca de nivel medio de Manchester investigado por Measham y Moore ${ }^{13}$ se componía de numerosos detalles sobre los tipos y marcas de ropa no permitidos en el local, descritos en un letrero junto a la entrada principal como «un código o política de acceso estricto pero justo». Y asi, se prohibían «las blusas recargadas de logotipos", "el exceso de joyas", "los trajes negros", "las camisas de leñador", "la ropa deportiva" y "las poses»; por el contrario, a los posibles clientes se les sugería llevar "vaqueros y camisetas de marca, cuanto más estilosos mejor", "zapatillas deportivas limpias y elegantes" y «botas Timberland». La aceptación de las camisas de cuadros era todo un dilema para el club, pues les dedicaban un párrafo más largo en el código de vestuario: la lista decía bien claro que "no se aceptan camisas de cuadros" y añadía una serie de mar- the club, ${ }^{5,8}$ preferring instead to promote specialist EDM to committed followers through the internet and other targeted promotional strategies. Furthermore, once inside, most clubgoers do not expect or want to be 'on display' to passersby. This results in the venues choosing not to announce themselves to the world. Customers often enter dark and anonymous doors leading down into basements, in a process described by Garrat as going down the rabbit hole and into Wonderland. ${ }^{53}$ Such clubs are relatively secretive places of retreat and escape populated by those seeking playspaces known only to the few. Doors may even remain unmarked and clues to the existence of a club may only be apparent late at night when queues form on the street outside.

One sees here that both Manchester city centre dance clubs who target cultural elites and West End nightclubs who target consumer elites are cautious to deter the casual visitor simply seeking a late-night drink, or dance. Indeed, the question of how to process those persons who present themselves for entry is a major concern for club operators. Across a range of venues, the queue is engineered or manipulated for a variety of reasons. Queues of customers awaiting entry can be used as a form of marketing; a sign of the venue's popularity, prestige, or scarcity value to passersby. For this reason, door staff may sometimes be instructed to make customers wait, regardless of necessity, particularly at weekends. ${ }^{54}$ The existence of a queue also implies vigilant, professional door staff taking their time to search and process potential customers, as well as a small gesture to assert their authority over customers - no-one enters a club without and until the door staff give permission. The waiting time also allows door staff to assess the level of intoxication and potential for trouble of queuing customers, as well as to appraise the suitability of clothing and overall appearance of such persons.

Complex processes of exclusion operate through the discretion of door staff, club management and events promoters, as well as through the door 'spotters' they employ to identify those deemed suitable or unsuitable for entry. Central to this are the stated dress codes which, at first glance, can appear highly prescriptive. For example, the dress code of a mid-sized Manchester dance club researched by Measham and Moore ${ }^{13}$ provided considerable detail regarding what types and brands of clothing would not be permitted inside the club, on a notice beside the main entrance, described as "a strict but fair dress code/ door policy". So "overly emblazoned logo tops", "excessive jewellery", "dark outfits", "townie long sleeve cotton tops", "sportswear" and "attitudes" were forbidden, whereas potential customers were encouraged to wear "smart trendy jeans and T-shirts, the funkier the better", "clean smart trainers" and "Timberland boots". The acceptability of check shirts appeared to be more of a dilemma for the club and involved a more detailed entry in the dress code: whilst the list specified "no check shirts" and provided a list of outlawed brands, it conceded that "tight fitting cowboytype shirts are acceptable". In case potential customers 
cas proscritas, pero puntualizaba que "se admiten camisas ceñidas tipo vaquero". Por si los clientes no "entendian" un código tan extenso, la lista iba más allá y explicaba que su intención era "crear un ambiente seguro con personas de gustos similares, a la moda y elegantesı. El problema, como ha observado Malbon ${ }^{8}$, es que la mayoría de los clientes de los discotecas se consideran a sí mismos a la moda y elegantes, definiéndose como opuestos al "público en general», del cual Malbon nunca ha encontrado a nadie que se considerase miembro. Esto contrasta fuertemente con la falta total de códigos concretos de indumentaria en muchos eventos de MDE pura y la ausencia de pretensiones de diferenciación cultural. En abierto contraste con la prohibición de disfraces en las discotecas del West End, en la Nochevieja de 2008 en el Fantazia de Birmingham, con nueve pistas y capacidad para 3.000 personas, y con el tema de los "héroes", no hubo código indumentario de ningún tipo e incluso se animó a los asistentes a disfrazarse. En el epígrafe del vestuario, la publicidad del evento decía «ninguno en especial (pero en consonancia con el ambiente y con accesorios de héroes o del mundo de las discotecas) $1^{55}$. Este tipo de eventos de MDE pura y dura, que atraen a varios miles de personas de clase obrera y rentas bajas todos los años, son la antítesis de las subculturas supuestamente "espectaculares" que los críticos de los estudios sobre los clubs consideran características de la música $\mathrm{MDE}^{56,57}$. Esto se observa en el consumo de drogas de tres discotecas diferentes estudiadas por Measham y sus colegas $^{15}$. En el local de varias pistas con clientes de clase obrera y de extracción socioeconómica inferior se consumian más anfetaminas (más baratas), éxtasis y cannabis, y mucha menos cocaína (más cara) y alcoholk.

Frente a la mística de cualquier cosa vale y uropa para sudar" de los eventos de MDE pura y dura como los de Fantazia, las discotecas céntricas especializadas en música house imponen un código indumentario de ropa "guay" y "enrollada", que provoca que algunos clientes sean rechazados por ir demasiado elegantes y resultar, por tanto, poco enrollados. Un cliente potencial de Sankeys, subdirector de una empresa de alquiler de camiones, fue rechazado porque su camisa y sus pantalones no "eran marchosos», a pesar de que protestó diciendo que "esa tarde había comprado una camisa George azul que le había costado $12 \mathrm{E}^{\prime}$ y había comprobado el código de vestuario del local en Internet antes de acercarse a la entrada ${ }^{58}$. En realidad, estos códigos indumentarios aluden sólo de modo superficial a la ropa y por ello provocan tanta confusión entre los excluidos, como lo demuestran las entrevistas con empleados de las discotecas que analizan los motivos ocultos detrás de esos códigos. El portavoz de una discoteca defendió esta exclusión en un periódico local afirmando: "No admitimos a gente con pinta de catetos, tribus urbanas $5^{59,60,61}$ o pandilleros. No se trata sólo de la ropa, sino de la actitud de la persona. Los verdaderos amantes de las discotecas, lo pasarán genial». Esto recuerda la justificación de la gerencia de una discoteca por rechazar a un hombre

\footnotetext{
Un tema del estudio sobre Discotecas y Drogas fue el de las diferencias entre distintos tipos de discotecas dentro de una misma ciudad británica, incluyendo las diferencias sociodemográficas de la clientela, el género de MDE y el consumo de drogas ilegales (Measham et al, 2001).

George es el nombre de una marca de ropa de supermercado muy barata que se fabrica para la venta en las cadenas Asda/Walmart de Gran Bretaña.
}

could not 'decode' such a lengthy dress code, the list also went beyond clothing to explicitly make its point that "it's all about creating a safe environment with cool trendy clubbing like-minded people". The challenge, as Malbon has noted in his research, is that most club-goers consider themselves to be cool and trendy, defining themselves in opposition to a 'mainstream' that Malbon has never met a self-proclaimed member of. This is in sharp contrast to the total lack of any specified dress code at many hardcore EDM events and the lack of claims to cultural distinction. Indeed in sharp contrast to the West End night club's ban on fancy dress, at the nine arena, 3,000 capacity, Fantazia New Year's Eve 2008 hardcore event in Birmingham with a 'Heroes' theme, there was no specified dress code but rather an encouragement to ravers to wear fancy dress. Under dress code, publicity for the event said "none (but do get with the atmosphere and wear Heroes or raver gear". ${ }^{55}$ Such hardcore EDM events, attracting many tens of thousands of working class and lower income club-goers each year, are the antithesis of the supposedly 'spectacular' style subcultures characterised as EDM by critics of Club Studies. ${ }^{56,57}$ This is illustrated in the patterns of dance drug use in three contrasting dance clubs in the study conducted by Measham and colleagues. ${ }^{15}$ It was the hardcore multiarena venue with customers drawn from working class and lower income socio-economic groupings, that had significantly higher use of (cheaper) amphetamines, ecstasy and cannabis, and significantly lower use of (more expensive) cocaine and alcohol. ${ }^{\mathrm{K}}$

In antithesis to the 'dress to sweat' anything-goes ethos of hardcore EDM events such as Fantazia, city centre dance clubs specialising in house music emphasise a dress code of 'cool' and 'funky' clothes, resulting in some potential customers being turned away for being too smart and thus, un-cool. One potential customer at Sankeys, an assistant manager of a truck hire company, was turned away because his shirt and trousers were considered to be "not funky enough", despite him protesting that he'd "even bought a new blue shirt from George for $£ 12$ that afternoon"l and had checked out the club's dress code online before attempting entry. ${ }^{58}$ In fact, it is because such dress codes relate only superficially to specific clothing that they produce such confusion amongst those excluded, as evident in interviews with club staff which explore the motivations behind such codes. A club spokesman defended this particular exclusion in a local newspaper, explaining that "we do not allow people who look like townies, chavs, ${ }^{59,60,61}$ or scallies. It is not always just about the dress code, it is about the person's attitude. If you are a genuine clubber, you will have a lot of fun". This echoes a justification by club management for the exclusion of a man from a different Manchester city centre club earlier the same year for wearing a stripy shirt, because in his

\footnotetext{
A theme in the Dancing on Drugs study was differences between three different types of dance clubs within one British city, including differences in sociodemographic customer base, genre of EDM and illicit drug use (Measham et al 2001).

George is the brand name for a collection of very cheap supermarket clothing manufactured for sale in Asda/Walmart in the UK.
} 
de otra discoteca del centro de Manchester que llevaba una camisa de rayas ese mismo año porque, en su opinión: "Los tipos que llevan camisas de rayas son problemáticos y pandi\|leros" ${ }^{62}$. Y así, el código indumentario se utiliza para excluir a los que se cree, partiendo sólo de una primera impresión, que proceden de ambientes más pobres ("catetos, tribus urbanas o pandillerosı) y tienen un menor capital (sub)cultural en el mundo de las discotecas. Esto se fundamenta en la valoración de la marca de ropa, en el estado de la misma, en su significado estilístico amplio y en la "actitud" del cliente, más que en la prenda de ropa concreta. Dichas personas no se consideran "discotequeros genuinos" y se rechazan por su capacidad potencial para "corromper el ambiente». Es aquí donde vemos la formulación más explícita de las élites culturales, cuando los clientes se quedan desconcertados al ser excluidos por seguir un código indumentario explícito sin descifrar el mensaje implícito de que no son bien recibidos porque son quienes son, no por su aspecto.

En el interior la distribución espacial de las discotecas refleja cada vez más la de otros locales de ocio del espectro musical. Hay una creciente segregación espacial de diferentes tipos de clientes y del distinto servicio que reciben del personal. Esto se aleja considerablemente de la antigua ética PAUR incluyente de la cultura rave y se retrotrae a la idea de los años 70 y principios de los 80 de la discoteca como lugar exclusivo en el que glamurosos derrochadores y élites consumistas exhibian su afluencia y su influencia. Los espacios VIP están representados de forma más gráfica en las grandes zonas de múltiples niveles de las súperdiscotecas de lbiza ${ }^{63}$; pero las entradas, las zonas y las mesas reservadas de antemano se han extendido últimamente por las discotecas de Gran Bretaña e incluso se ofrecen en la "capital del rave», Sankeys. Como destaca el clásico estudio etnográfico de Spradley y Mann sobre los bares americanos en los años $70^{64}$, las demarcaciones informales existen también en los locales más pequeños ${ }^{65}$. El trabajo de observación revela que incluso las discotecas sin zona VIP ni demarcaciones formales de espacio contienen círculos de importancia concéntricos, que se extienden es espiral desde la barra, el personal de seguridad, los asientos y lugares de privilegio que permiten ver a todo el mundo, en los que se sitúan el dueño del local, los DJ y los MC cerca del escenario, el tocadiscos y los altavoces. Sólo los más próximos al DJ y al séquito del dueño pueden estar cerca del escenario; los demás que accedan a dicho espacio, deberán tener un motivo, como transmitir un mensaje o una petición o hacer una foto. Esos sanctasanctórum son cada vez más visibles, incluso en los eventos de rave puro y duro, y se puede acceder a los mismos pagando un precio. Por ejemplo, en la antedicha fiesta de Nochevieja de 2008 los promotores del Fantazia vendieron entradas normales a $35 €$ y entradas VIP a $55 €$, éstas con "una consumición gratis, acceso a la zona VIP y oportunidad de conocer a los artistası.

\section{DISCUSIÓN}

Este artículo se añade al reciente interés por entender los matices de la cultura de discoteca y de la EON. Al analizar el establecimiento y promoción de noches especiales y las for- opinion: "people who wear stripy shirts are trouble causers and scallies". ${ }^{62}$ Thus, the dress code is used to exclude those who are judged, purely on first impressions to come from lower income backgrounds ("townies, chavs, or scallies") and to have lower (sub)cultural capital in clubland. The latter might relate to assessments of the brand of clothing, the way it is worn, its broader stylistic significance and the "attitude" of the club-goer, more than to what the specific item of clothing is. Such people are judged not to be "genuine clubbers" and are reviled for their potential capacity to 'spoil the atmosphere' for those who are. It is here we see the most explicit formulation of cultural elites, with potential clubgoers baffled at their exclusion for following an explicit dress code without decoding the implicit message that they are not welcome because of who they are, rather than because of how they look.

Once inside, the spatial organisation of dance clubs increasingly echoes that of other leisure venues across the musical spectrum. One sees a growth in the spatial segregation of different groups of customers and in the differentiation of service they receive from staff. All of this, of course, departs significantly from the earlier inclusionary PLUR ethos of rave culture, returning instead to 1970s and early-1980s notions of the nightclub as an exclusive space in which glamorous high spenders and consumer elites displayed their affluence and influence. The addition of VIP spaces is perhaps most graphically represented in the large, multi-level and distinct zones within Ibiza superclubs: ${ }^{63}$ but VIP tickets, VIP areas and designated pre-booked tables have recently encroached into dance clubs across the UK and are even offered at the "rave capital", Sankeys. As Spradley and Mann's classic 1970s ethnography of American bars highlights, ${ }^{64}$ informal demarcations operate within even the smallest of licensed premises. ${ }^{65}$ Observational work reveals how even dance clubs, with no VIP area or other formal demarcations of space, contain concentric circles of importance, spiralled out from the bar, security staff, seating and the premium positions which often overlook the crowd where the club promoter, DJs and MCs cluster near the stage, turntable and speakers. In effect, only those closely connected with the DJ and promoter's entourage are able to stand on or near the stage area and others who enter this space would be expected to have a reason, such as to pass on a message or request, or take a photograph. Such inner sanctums are increasingly evident, even at hardcore rave events, with access available at a price. For example, at the aforementioned multi-arena New Year's Eve 2008 party, promoters Fantazia sold standard tickets for $€ 35$ and VIP tickets for $£ 55$, the latter promising "one free drink, VIP room access and a chance to meet the artists".

\section{DISCUSSION}

This paper adds to the recent focus on understanding the nuances both within club cultures and across the NTE. By considering the establishment and promotion of club nights 
mas en que se anima o se disuade a los potenciales clientes, esos procesos informales llevan a la producción y reproducción de dos variantes opuestas de élites del mundo de las discotecas: las "élites culturales», generadas por la marginación y la exclusión social, cultural y espacial de la MDE negra y de sus seguidores de minorías étnicas y clase obrera de las discotecas del centro de Manchester, y las «élites consumistas" generadas por la exclusión económica y cultural de los clientes de clase obrera y rentas bajas de los clubs del West End londinense.

Estas tendencias tienen importantes consecuencias sociales: por ejemplo, crean una situación en la que grandes grupos de electores de clase obrera y rentas bajas de los sectores nocturnos tradicionales de Londres han sido privados de sus derechos en la EON del West End. Como declaró el dueño de un club del West End en una sesión para la concesión de licencias del Ayuntamiento de Westminster: "La admisión de quienes no son miembros no añadiría valor al lugar; es más, creo que ocasionaría problemas». Las razones explicitas para dichas exclusiones se basan en la identificación y reducción de los riesgos derivados de unas consumiciones escasas, un nivel bajo, y supuestamente unos grupos socioeconómicos más delictivos. Se trata de conceptos claros, casi fascistas, de pureza social y de limpieza étnica, lo cual indica que los sociólogos que estudian la cultura juvenil y las transiciones de los jóvenes pasan por alto la cuestión del acceso a las oportunidades de ocio en la EON y describen la discriminación institucional dentro de las industrias recreativas como les da la gana. Los temas se extienden a la exclusión espacial del centro de la ciudad, con ambientes sociales enteros a los que se le niega el acceso en los locales de primera categoría a través de procesos de gobernabilidad informales y privados muy difíciles de ver para el observador ocasional y no responsables en términos democráticos. En vez de "paz, amor, unidad y respeto", se utiliza un lenguaje de miedo y odio para etiquetar, denunciar y expulsar a los no invitados a la fiesta: los "pandilleros", las "tribus urbanas", los "catetos", y "su» música.

La observación detallada de estas prácticas sociales en los ambientes de ocio local proporciona una saludable visión del tejido social y cultural de la sociedad británica y en particular de su fragmentación continua siguiendo líneas de clase social y desigualdad material ${ }^{66}$. Hasta el punto de que la inclusión en grupos paritarios y el acceso a los ambientes de ocio local representan recursos valiosos y repartidos de modo desigual por los que los jóvenes han de competir, mientras que las "opciones" estéticas declaradamente frivolas y las sutiles manifestaciones de fidelidad a una marca 0 de resistencia se cargan de significado en la EON. En términos de Bourdieu ${ }^{67}$, los espacios nocturnos de una élite cultural y comercialmente gentrificada ejercen una forma de "violencia simbólica», en la que el valor relativo, el significado y la "percepción" de ciertos productos, experiencias y espacios son impuestos por los posesores del capital económico y (sub) cultural, en grave detrimento de los que carecen de él. Y así, grandes proporciones de jóvenes son excluidos de dichos espacios directamente, prohibiéndoseles la entrada, 0 indirectamente, haciendo que se sientan incómodos o indig- and the ways that potential customers are encouraged or discouraged from admission, these informal processes together result in the production and reproduction of two contrasting forms of clubbing elites; 'cultural elites' produced through the marginalisation, social, cultural and spatial exclusion of black EDM and its minority ethnic and working class followers from Manchester city centre dance clubs, and 'consumer elites' produced through the economic and cultural exclusion of working class and lower income club-goers from nightclubs in London's West End.

These trends are having important social effects, for example, creating a situation in which large swaths of nocturnal London's traditional working class and lower middleclass constituency have become disenfranchised from the West End NTE. As one West End club owner opined in oral evidence at a Westminster City Council licensing hearing: "the admittance of non-members would not add value to the site, indeed, I believe it would create issues". The explicit reasons for such exclusions relate to identifying and reducing the risks associated with lower spending, lower status, and supposedly more crimogenic socio-economic groups. There are distinct, almost fascistic, notions of social purity and ethnic cleansing at work here which suggest that social scientists interested in youth culture and young people's transitions ignore the issue of access to leisure opportunities in the NTE and underlying institutional discrimination within the creative industries at their peril. The issues broaden out to those of spatial exclusion from the central city, with entire social scenes denied access to premium venues through processes of informal and privatised governance that are largely opaque to the casual observer and democratically non-accountable. Rather than 'peace, love, unity and respect', a language of fear and loathing is employed to label, denounce and expel those not invited to the party the 'gangsters', 'chavs', 'scallies' and 'their' music.

Close attention to such social practices within local leisure scenes provides a salutary window onto the wider social and cultural fabric of British society and in particular its continued fragmentation along lines of social class and material inequality. ${ }^{66}$ To the extent that peer group inclusion and access to local leisure scenes represent both valued and differentially allocated resources over which young people must compete, ostensibly frivolous aesthetic 'choices' and stylized displays of brand loyalty and resistance in the NTE appear laden with meaning. In Bourdieu's terms, ${ }^{67}$ gentrified, commercially and culturally elite nightlife spaces exert a form of 'symbolic violence', wherein the relative value, meaning, and 'feel' of certain products, experiences and spaces is imposed by the holders of economic and (sub)cultural capital, largely to the detriment of those who lack it. Thus, large proportions of young people are excluded from such spaces, either directly, through being denied entry, or indirectly, by being made to feel uncomfortable or unworthy. "Symbolic violence is effective precisely because those upon whom it acts feel intimidated and constrained by it without recognizing the intimidation and constraint as domination". ${ }^{68}$ Our 
nos. "La violencia simbólica es eficaz porque aquellos sobre quienes actúa se sienten intimidados y constreñidos por ella, sin reconocer la intimidación y restricción como dominio" ${ }^{68}$. Nuestro estudio en pueblos y ciudades de Inglaterra indica que en el fondo están cada vez más excluidos de la diversión, y que beben y se relacionan en casa ${ }^{69}$, con sus vecinos más próximos ${ }^{10}$, o en la calle $\mathrm{e}^{70}$. Resulta aún más llamativo el alcance de la convergencia internacional e intercultural en el aumento de la exclusión social de la vida nocturna comercial, especialmente a través de la vigilancia y criminalización de los jóvenes menos privilegiados. En Gran Bretaña ese fenómeno se enmarca en un contexto político más amplio que incluye la liberalización del ocio autorizado y la expansión de la EON vinculada al alcohol (para algunos), frente a la creciente criminalización de la "conducta antisocial" de bajo nivel en lugares públicos y el control de los clientes de las discotecas a través de la "prohibición proactiva" del consumo de drogas en discotecas los fines de semana ${ }^{71}$.

\section{AGRADECIMIENTOS}

Nuestro agradecimiento a los organizadores del Congreso Club Health 2008 por su gran trabajo, a los editores de Adicciones, a Karenza, a los dos revisores que han aportado una perspectiva americana, y a Alasdair Forsyth por sus comentarios sobre Escocia: ¡Unidos en el baile, divididos por un idioma común!

\section{REFERENCIAS / REFERENCES}

1. Weber T. Raving in Toronto: Peace, Love, Unit and Respect in Transition. Journal of Youth Studies. 1999; 2(3):317-36.

2. Riley S. Morey Y. Griffin, C. Ketamine: The divisive dissociative - a discourse analysis of the construction of ketamine by participants of a free party (rave) scene, Addiction Research and Theory 2008; 16(3): 217-30.

3. St John G. editor. Rave culture and religion. London: Routledge; 2004.

4. McKay G. editor. DiY culture: party and protest in nineties britain, London: Verso; 1998.

5. Hunt G. Moloney M. Evans, K. Youth, drugs and nightlife. New York: Routledge; 2009

6. Böse M. Difference and exclusion at work in the club culture economy. International Journal of Cultural Studies. 2005; 8(4): 427-44.

7. Hutton F. Risky pleasures? club cultures and feminine identities. Aldershot: Ashgate; 2006

8. Malbon B. Clubbing: dancing, ecstasy and vitality. London: Routledge;1999.

9. Thornton S. Club cultures: music, media and subcultural capital. Cambridge: Polity; 1995.

10. Talbot D. Regulating the night: race, culture and exclusion in the making of the night-time economy. Aldershot: Ashgate; 2007. Talbot D. Regulation and racial differentiation in the research in towns and cities across England suggests that those at the bottom are increasingly excluded from the party altogether, drinking and socialising at home, ${ }^{69}$ in their immediate neighbourhood, ${ }_{1}^{10}$ or on the streets. ${ }^{70}$ Even more notable is the extent of international and cross-cultural convergence in the rise of social exclusion from commercial nightlife, particularly through the surveillance and criminalisation of less privileged young people. In the UK, this is located in a wider policy context which includes the liberalisation of licensed leisure and expansion of the alcohol-oriented NTE (for some), contrasted with the increased criminalisation of low level 'anti-social behaviour' in public spaces and the policing of club-goers through "proactive prohibition" of weekend club drug use. ${ }^{71}$

\section{ACKNOWLEDGEMENTS}

With thanks to the Club Health 2008 conference organisers for their hard work; to the editorial staff at Adicciones; to Karenza; to the two reviewers for an American perspective and to Alasdair Forsyth for a Scottish perspective on this paper - united in dance, divided by a common language! construction of night-time economies: a London case study. Urban Studies. 2004; 41(4): 887-901.

11. Hobbs D. Hadfield P. Lister, S. Winlow, S. Bouncers: violence and governance in the night-time economy. Oxford: Oxford University Press; 2003

12. Criminology and Criminal Justice, special issue: urban safety, anti-social behaviour and the night-time economy. 2009; 9(4).

13. Measham F. Moore, K. Repertoires of distinction: exploring patterns of weekend polydrug use within local leisure scenes across the English night-time economy. Criminology and Criminal Justice 2009; 9(4): 437-464.

14. Hadfield P. Measham, F. Shaping the night: how licensing, social divisions, and informal social controls, mould the form and content of nightlife. Crime Prevention and Community Safety. An International Journal 2009; 11(3): 219-34.

15. Measham F. Aldridge J. Parker H. Dancing On drugs: risk, health and hedonism in the British club scene. London: Free Association Books; 2001.

16. Measham F. Moore K. Reluctant reflexivity, implicit insider knowledge and the development of club studies. In Sanders B, editor. Drugs, clubs and young people: sociological and public health perspectives. Aldershot: Ashgate; 2006. p. 13-25.

17. Hadfield P. Bar wars: contesting the night in contemporary British cities. Oxford: OUP; 2006. Hadfield P, editor. Nightlife and crime: social order and governance in international perspective. Oxford: Oxford University Press; 2009. 
18. Hadfield P. From threat to promise: nightclub 'security' governance and consumer elites. British Journal of Criminology 2008; 48: 429-47.

19. Home Office/KPMG Review of the social responsibility standards for the production and sale of alcoholic drinks. Birmingham: KPMG LLP; 2008.

20. Chatterton P. Hollands R. Urban nightscapes: youth cultures, pleasure spaces and corporate power. London: Routledge; 2003.

21. Savage M. Williams K. Elites: remembered in capitalism and forgotten by social sciences. The Sociological Review, special issue: taking stock of elites: recognizing historical changes 2008; 56(s1): 1-24.

22. Scott F. Modes of power and the re-conceptualization of elites. In Savage M Williams K, editors. The Sociological Review, special issue: taking stock of elites: recognizing historical changes; 2008; 56(s1): 27-43. See also Scott, J, editor. The sociology of elites, three volumes. Cheltenham: Edward Elgar Publishing; 1990. Scott J. Power. Cambridge: Polity Press; 2001.

23. Bourdieu P. Distinction: a social critique of the judgement of taste. London: Routledge; 1984.

24. Perrone D. The high life: club kids, harm and drug policy. Monsey: Criminal Justice Press; 2009.

25. McRobbie A. Clubs to companies. notes on the decline of political culture in speeded up creative worlds. Available from: URL: http://www.nelp.de/beitraege/02_farbeit/mcrobbie_e.doc

26. Haslam D. Manchester, England: the story of the pop cult city. London: Fourth Estate; 1999.

27. Hayward K. City limits: crime, consumer culture and the urban experience. London: Glasshouse; 2004.

28. Böse M. Manchester's cultural industries: a vehicle of racial ex/ inclusion? In Eckardt F. Hassenpflug, D, editors. Consumption and the post-industrial city. Frankfurt/New York: Peter Lang; 2003. p.167-78.

29. Becker H. Outsiders: studies in the sociology of deviance. New York: Free Press; 1963.

30. Gilroy P. There ain't no black in the union jack: the cultural politics of race and nation. London: Hutchinson; 1987.

31. Griffin C. Representations of youth: the study of youth and adolescence in Britain and America. Cambridge: Polity Press; 1993.

32. Kohn M. Dope girls: the birth of the British drug underground. London: Lawrence \& Wishart; 1992.

33. Talbot $D$, Böse M. Racism, criminalization and the development of night-time economies: Two case studies in London and Manchester. Ethnic and Racial Studies 2007; 30(1): 95-118.

34. Kirby P. Social exclusion in Manchester club culture. Unpublished MA dissertation in Music Industry Studies. University of Liverpool; 2008.

35. Hadfield P. Lister S. Traynor P. This Town's A Different Town Today: Policing and Regulating the Night-time Economy. Criminology and Criminal Justice 2009; 9(4): 465-485.

36. Jones S. Black culture white youth: the reggae tradition from JA to UK. Basingstoke: Macmillan Education; 1988.

37. Gilroy P. Lawrence E. Two-tone Britain: white and black youth and the politics of anti-racism. In Cohen P. Bains $H_{\text {, editors. }}$ Multi-racist Britain. Basingstoke: Macmillan; 1988. p.121-155.

38. Rowlands M. The Guardian. The Guide Clubs preview. 8th Apr 2006; 32-3.
39. Birnie J. Skeggs B. Cosmopolitan knowledge and the production and consumption of sexualized space: Manchester's gay village. Sociological Review; 2004; 52: 39-61.

40. Quilley S. Constructing Manchester's 'new urban village': gay space in the entrepreneurial city. In Ingram G, Bouthillette A-M, Retter Y. editors. Queers in space: communities, public spaces, sites of resistance; 1987. p. 275-94.

41. Lovatt A. The ecstasy of urban regeneration: regulation of the night-time economy in the transition to a post-fordist city. In O'Connor J, Wynne D. editors. From the margins to the centre: cultural production and consumption in the post-industrial city. Aldershot: Arena. 1996; 141-68.

42. Savage J, editor. The Haçienda must be built! Woodford Green: International Music Publications; 1992.

43. Night. London calling: member's club market in overdrive. 2007 June; 22-31. p. 27.

44. Night. Amika: exclusive new venue stakes a claim on celebrity crowds. 2007 May; 27-9. p. 29.

45. Moloney M, Hunt G, Bailey N, Erez G. New forms of regulating the night-time economy - the case of San Francisco. In Hadfield P, editor. Nightlife and Crime: Social Order and Governance in International Perspective. Oxford: Oxford University Press. 2009. p. 151-80.

46. Swanton 0. Gangchester. Mixmag 1998: 81 Feb. p. 68-76.

47. The Guardian. The guide, clubs: Manchester International Festival. 2009; 27 June. p. 34.

48. Eyre A. Breakfast in Brixton. Night 2006; October: 32-5. p.34.

49. Ferrell J. Style matters. In Ferrell J, Hayward K, Morrison W, Presdee M. editors. Cultural Criminology Unleashed. London: Glasshouse; 2004.

50. Moore K. A commitment to clubbing. Peace Review: A journal of social justice 2004; 16(4): 459-565.

51. Siokou C, Moore D. This is not a rave! changes in the commercialised Melbourne rave/dance party scene. Youth Studies Australia 2008; 27(3): 50-7.

52. Hadfield P. The operation of licensed premises. In Kolvin P. editor. Licensed Premises: Law and Practice. London: Tottel; 2004. p. 234-76.

53. Garratt S. Adventures in wonderland: a decade of club culture. London: Headline; 1998.

54. Measham F, Brain K. 'Binge' drinking, British alcohol policy and the new culture of intoxication. Crime, Media, Culture: An international journal 2005; 1(3): 263-84.

55. Available from: URL: http://www.fantazia.org.uk/Event\%20info/ fantazia_newyear08_queclub.htm [accessed $30^{\text {th }}$ June 2009].

56. Shildrick T, MacDonald R. In defence of subculture: young people, leisure and social divisions. Journal of Youth Studies 2006; 9(2): 125-40.

57. Miles $S$. Youth lifestyles in a changing world. Buckingham: OUP; 2000.

58. Manchester Evening News. Club rejects 'not funky enough'. 2009; $6^{\text {th }}$ Apr: Available from: URL:http://www. manchestereveningnews.co.uk/news/s/1003/1003833_club_ rejects_not_funky_enough.html [accessed 30th June 2009].

59. Hayward K, Yar M. The 'chav' phenomenon: consumption, media and the construction of a new underclass. Crime, Media, Culture 2006; 2(1): 9-28.

60. Nayak A. Displaced masculinities: chavs, youth and class in the post-industrial city. Sociology 2006; 40(5): 813-31. 
61. Martin G. Subculture, style, chavs and consumer capitalism: towards a critical cultural criminology of youth. Crime Media Culture 2009; 5(2): 123-45.

62. The Guardian. No hoods... or striped shirts. 2009; $5^{\mathrm{t}}$ February. Available from URL: http://www.guardian.co.uk/uk/2007/feb/05/ davidward.uknews4 [accessed $30^{\text {th }}$ June 2009].

63. Anderson T. Rave culture: the alteration and decline of a music scene. Philadelphia, USA: Temple University Press; 2009.

64. Spradley J, Mann B. The cocktail waitress: woman's work in a man's world. New York: John Wiley; 1975.

65. Owen S. Pubs, clubs and restaurants: the impact of the new Licensing Act together with a difficult trading environment and other new legislation on capital and rental values of UK nightclubs. Journal of Retail and Leisure Property 2006; 5(4): 341-53.

66. Sveinsson KP. Who cares about the white working class? London: The Runnymede Trust; 2009.

67. Bourdieu P. In other words: essays towards a reflexive sociology. Trans. Matthew Adamson. Stanford: Stanford University Press; 1990.
68. Wood JK Refined raw: the symbolic violence of victims' rights reforms. College Literature 1999; Winter. p. 8. Available from: URL: http://findarticles.com/p/articles/mi_qa3709/is_199901/ ai_n8849488 [accessed $28^{\text {th }}$ January 2009].

69. Hughes K, Anderson Z, Morleo M, Bellis M. Alcohol, nightlife and violence: the relative contributions of drinking before and during nights out to negative health and criminal justice outcomes. Addiction 2007; 103: 60-5.

70. Coleman L, Cater S. Underage 'risky' drinking: motivations and outcomes. York: Joseph Rowntree Foundation; 2005. Galloway J, Forsyth A, Shewan D. Young people's street drinking behaviour: investigating the influence of marketing and subculture. Glasgow: Glasgow Centre for the Study of Violence, Glasgow Caledonian University. final report for the AERC; 2007.

71. Measham F, Moore K. The criminalisation of intoxication. In Squires $P$, editor. ASBO Nation: The criminalisation of nuisance. Bristol: Policy. 2008: p. 273-88. 